\title{
Franz Josef Land: extreme northern outpost for arctic fishes
}

Natalia N.V. Chernova, Alan M Friedlander, Alan Turchik, Enric Sala

The remote Franz Josef Land (FJL) Archipelago is the most northerly land in Eurasia and its fish fauna, particularly in nearshore habitats, has been poorly studied. An interdisciplinary expedition to FJL in summer 2013 used scuba, seines, and plankton nets to comprehensively study the nearshore fish fauna of the archipelago. We present some of the first underwater images for many of these species in their natural habitats. In addition, deep water drop cameras were deployed between 32 and $392 \mathrm{~m}$ to document the fish fauna and their associated habitats at deeper depths. Due to its high latitude $\left(79^{\circ}-82^{\circ} \mathrm{N}\right)$, extensive ice cover, and low water temperatures $\left(<0^{\circ} \mathrm{C}\right.$ much of the year), the fish diversity at FJL is low compared to other areas of the Barents Sea. Sixteen species of fishes from seven families were documented on the expedition, including two species previously unknown to the region. One Greenland shark, Somniosus microcephalus (Somniosidae), ca. $2 \mathrm{~m}$ in length, was recorded by drop camera near Hayes Island at $211 \mathrm{~m}$, and Esipov's pout, Gymnelus esipovi (Zoarcidae), was collected at Wilton Island at $15 \mathrm{~m}$ in a kelp forest. Including the tape-body pout, Gymnelus taeniatus, described earlier from the sub-littoral zone of Kuhn Island, 17 fish species are now known from FJL's nearshore waters. Species endemic to the Arctic accounted for $75 \%$ of the nearshore species observed, followed by species with wider ranges. A total of 43 species from 15 families are known from FJL with the majority of the records from offshore trawl surveys between 110-620 m. Resident species have mainly high Arctic distributions, while transient species visit the archipelago to feed (e.g., Greenland shark), and others are brought by currents as larvae and later migrate to spawn grounds in the south (e.g., Atlantic cod Gadus morhua, Capelin Mallotus villosus, Beaked redfish Sebastes mentella). Another species group includes warmer-water fishes that are rare waifs (e.g., Glacier lanternfish Benthosema glaciale, White barracudina Arctozenus rissoi). The rapid warming of the Arctic will likely result in significant changes to the entire ecosystem and this study therefore serves as an important baseline for the nearshore fish assemblages in this unique and fragile region. 
1

2

3

4

5

6
Natalia V. Chernova ${ }^{1}$, Alan M. Friedlander ${ }^{2,3}$, Alan Turchik ${ }^{2}$, Enric Sala ${ }^{2}$ ${ }^{1}$ Zoological Institute of Russian Academy of Sciences, St. Petersburg, Russia

${ }^{2}$ National Geographic Society, Washington, DC, USA

${ }^{3}$ Fisheries Ecology Research Laboratory, University of Hawaii, Honolulu, USA Corresponding author: Alan M Friedlander, Fisheries Ecology Research Laboratory, University of Hawaii, Honolulu, USA, alan.friedlander@hawaii.edu, 808-956-3425 


\section{Introduction}

8 Owing to its unique biogeographic and climatic histories, the Arctic Ocean has produced a

9 distinctive fish fauna dominated by phylogenetically young families (e.g., Zoarcidae,

10 Stichaeidae) (Andriashev, 1939; Dunbar, 1968; Mecklenburg, Møller \& Steinke, 2010). Older

11 groups eliminated during the rapid cooling of the Middle Miocene were followed by younger

12 families invading the Arctic mainly from the Pacific via the opening of the Bering Strait 3-3.5

13 million years ago (Andriashev, 1939; Savin, 1977; Mecklenburg, Møller \& Steinke, 2010), while

14 a few families have also invaded the region from the Atlantic (e.g., Gadidae, Anarhichadidae)

15 (Svetovidov, 1948; Mecklenburg, Møller \& Steinke, 2010). Of the 504 species currently

16 comprising the Arctic ichthyofauna, those with Atlantic-Arctic ranges comprise 58\% of the total

17 richness, followed by species with Pacific-Arctic ranges (20\%), while those endemic to the Arctic

18 region account for an additional 14\% (Chernova, 2011).

19 The Franz Josef Land (FJL) Archipelago is located within the Barents Sea Large Marine

20 Ecosystem, which is a transition zone where relatively warm, more saline water from the Atlantic

21 mixes with Arctic and Polar waters (Johannesen et al., 2012a). These oceanographic conditions

22 result in high productivity (Cochrane et al., 2009) that supports major fisheries, including the

23 largest remaining stock of Atlantic cod (Gadus morhua) (Johannesen et al., 2012b). Currently >

24200 fish species from 66 families are found in the Barents Sea (Stiansen \& Filin, 2008, Dolgov,

25 2011). The dominant families are: eelpouts (Zoarcidae), sculpins (Cottidae), codfishes (Gadidae),

26 snailfishes (Liparidae), flatfishes (Pleuronectidae), which collectively account for nearly 80\% of

27 the species regularly occurring in the Barents Sea.

28 FJL is a zakaznik (protected area, equivalent to IUCN category IV), currently managed by the 29 Russian Arctic National Park. Its remoteness and harsh physical environment makes it one of the 30 least known places on earth. The archipelago is situated in the NE Barents Sea $\left(79^{\circ}-82^{\circ} \mathrm{N}, 43^{\circ}-\right.$ $3167^{\circ} \mathrm{E}$ ) and consists of 192 islands, covering 16,134 $\mathrm{km}^{2}$ (Barr, 1994) Although FJL lies at the 32 same latitude as Svalbard, Norway, the fish assemblages are very different (Fossheim, Nilssen \& 33 Aschan, 2006; Stiansen et al., 2009). The warm Atlantic currents that run along the northern 34 continental slope of the Barents Sea, are greatly diminished by the time they reach FJL (Schauer 35 et al., 2002), resulting in a biota consisting mainly of cold-water organisms (Wassmann et al., 
36 2006). Because of remoteness and severe ice conditions most of the year, the FJL fish fauna has

37 not been well studied.

38 Previous fish survey of FJL

39 The first records of fishes from FJL come from the Austro-Hungarian expedition of 1872-74,

40 which noted blackbelly snailfish (as Liparis gelatinosus) and polar cod (as Gadus morue) (Payer,

41 1878). During the Norwegian Polar Expedition of 1893-1896, polar cod (Boreogadus saida)

42 were observed in the stomachs of several sea bird species (Collett \& Nansen, 1899). The 1894-97

43 British Expedition to FJL spent a winter at Cape Flora on Northbrook Island and collected a few

44 polar cod (Jackson, 1899). The same species was collected by the Italian expedition led by Duke

45 of the Abruzzi, Luigi Amedeo, which wintered on Rudolf Island in 1899-1900 (Camerano, 1903).

46 In 1901, a Russian expedition to FJL on the ice-breaker Ermak identified nine species of fishes at

47 depths from 24 to $358 \mathrm{~m}$. The Russian ice-breaker Georgiy Sedov visited FJL in 1929 and

48 collected Polar cod, twohorn sculpin (Icelus bicornis), and kelp snailfish (Liparis tunicatus)

49 (Esipov, 1931; Esipov, 1933). An oceanographic expedition in 1955 conducted by the Soviet

50 Arctic Institute (now AARI, St. Petersburg) surveyed the margins of the continental shelf north of

51 FJL using trawls and collected ten species of fishes (Andriashev, 1964; Koltun, 1964). In 1980-

52 90s the Knipovitch Polar Research Institute of Marine Fisheries and Oceanography (PINRO,

53 Murmansk) conducted benthic and pelagic trawls in the north-eastern Barents Sea, mainly 50-60

54 nm south-west of FJL in the Franz-Victoria Trough (depth 170-620 m), and collected 33 fish

55 species, (Borkin, 1993).

56 The expedition of the Zoological Institute of the Russian Academy of Sciences (ZIN) to FJL in

57 1981-82 used scuba to collect nearshore fishes. In 1991 and 1992, the expedition of the

58 Murmansk Marine Biological Institute (MMBI) conducted additional scuba sampling at FJL,

59 resulting in new information on three species of snailfishes (Chernova, 1993; Chernova, 2007). In

60 addition, a new zoarcid fish, the tape-body pout Gymnelus taeniatus was described from one

61 specimen found in the sub-littoral zone off Kuhn Island (Chernova, 1999a).

62

63 Surveys of the Barents Sea were conducted from 2004-2009 under the Russian-Norwegian

64 Cooperation Program, and resulted in an atlas of Barents-Sea fishes (Wienerroither et al., 2011).

65 More than 30 species were listed from FJL, including the White barracudina, Arctozenus risso, 
66 and Esmark's eelpout, Lycodes esmarkii. PINRO produced a key to the identification of

67 Barents Sea fishes that listed 11 species for FJL including the thorny ray, Amblyraja radiata, 68 which was collected near Alexandra Land and Prince George Land (Dolgov, 2011).

69 Currently, a total of 43 fish species from 15 families and 9 orders are known from FJL, with most 70 species collected by trawling southwest of the archipelago at depths from 100-600 $\mathrm{m}$ (Table S1).

71 In the summer of 2013, an interdisciplinary research expedition to FJL, led by the National

72 Geographic Society and the Russian Arctic National Park conducted an assessment of the

73 biodiversity of the ichthyofauna using a suite of sampling methods with the objectives of

74 describing the taxonomy and ecology of the nearshore ichthyofauna, while also exploring the

75 deep sea environment around the archipelago.

76 MATERIALS AND METHODS

77 Sample design

78 Nearshore fishes were collected using 1) scuba and snorkeling, 2) beach seines, 3) plankton net, 79 and 4) samples regurgitated from seabirds. Observations and in situ photography were also used 80 to conduct species identification. Approval to conduct research on vertebrate animals was granted 81 by the Russian Federation Ministry of Education and Science Approval Ref. No. 14-368 of 82 06.05.2013. Approval to conduct field studies was granted by the Russian Federation Ministry of 83 Education and Science Approval Ref. No. 14-368 of 06.05.2013 permission to the Russian Arctic 84 National Park.

\section{Diving methods}

86 Three groups of divers conducted 68 dives at 19 localities at depths ranging from 0 to $34 \mathrm{~m}$ 87 around the archipelago (Fig. 1). While diving, fish samples were collected using hand aquarium 88 nets, nets and clove oil, or by hand. In addition, photographs were taken in situ to document 89 underwater coloration and associated habitat.

\section{Beach seines}

91 Beach seines were used at four locations: Tikhaya Bay at Hooker Island (40 hauls), Cape

92 Tegetthoff at Hall Island (6 hauls), Nilsen Bay at Bell Island (4 hauls) and Phoka Bay at

93 Northbrook Island (6 hauls). The seine was $10 \mathrm{~m}$ long by $2 \mathrm{~m}$ high with $10 \mathrm{~mm}$ stretch mesh. 


\section{PeerJ Reviewing Manuscript}

\section{Plankton net}

95 Larval and young-of-year fishes were collected by plankton net. Plankton sampling was

96 conducted at 20 locations, primarily in the straits between islands at depths between 200-340 m,

97 using vertical hauls from the bottom to surface. Plankton nets were of standard construction, with

98 a mesh of $0.2 \mathrm{~mm}$ or $0.074 \mathrm{~mm}$.

\section{Deepwater drop camera}

100 To explore the deep sea environments, deep drop-camera surveys were conducted. National

101 Geographic's Remote Imaging Team developed Deep Ocean Drop-cams, which are high

102 definition cameras (Sony Handycam HDR-XR520V 12 megapixel) encased in a borosilicate

103 glass sphere and rated to $10,000 \mathrm{~m}$ depth. Viewing area per frame was between 2-6 $\mathrm{m}^{2}$, depending

104 on the steepness of the slope where the Drop-cam landed. Cameras were baited with $1 \mathrm{~kg}$ of

105 frozen herring (Clupeidae) placed in a burlap bag and deployed for ca. four hours. The number of

106 individuals of each taxa per drop-cam deployment was estimated from the maximum number of

107 individuals observed per frame $\left(\mathrm{N}_{\max }\right)$.

\section{Field processing of fish samples}

109 Collected fishes were measured and weight on board and preserved in $4 \%$ buffer formaldehyde

110 solution. Samples were send to the Zoological Institute, St. Petersburg, Russia (entry number ZIN

111 № 6-013) and examined by the senior author. Vertebra and fin ray number were counted on

112 radiograms.

113 Abbreviations: dp - depth, coll. - collector, I. - Island; lc - head length, spl - sample, st - station,

114 sp - specimen; SL - standard length (from tip of snout to bases of caudal-fin rays), TL - total

115 length. Fins: A - anal, D - dorsal, C - caudal, P - pectoral, V - ventral. Format of dates: day,

116 month, year. DC - drop camera observations, MC - materials collected, VO - visual

117 observations. Sample number are as follows: ZIN collection number (6-013) and fish

118 identification number. For example, fish 22 is denoted as: ZIN 6-013/22.

\section{RESULTS}

120 Our expedition identified sixteen species of fishes from seven families and three orders in the

121 waters around FJL (Table 1). Of these, Scorpaeniformes was the most specious order, accounting

122 for $81 \%$ of all species observed (Table 2). Species endemic to the Arctic accounted for $75 \%$ of 
123 the nearshore species observed (three-fourths of which had circumpolar distribution), followed by

124 species with wider ranges, including the N. Atlantic and N. Pacific. Species with benthic or meso-

125 benthic habitat preferences accounted for $75 \%$ of the observed nearshore assemblage, followed

126 by bentho-pelagic species (18.8\%), and one cryopelagic and benthopelagic species, Boreogadus

127 saida. FJL nearshore waters are at the upper limit of vertical distribution for fishes of all species.

128 The vast majority of the fishes observed around FJL were invertebrate feeders, while three were

129 facultative piscivores (e.g., Greenland shark, Atlantic cod, Parr's snailfish), with one - the

130 cryopelagic polar cod - feeding primarily on zooplankton under the ice.

\section{Drop-cams}

132 A total of 24 camera drops were conducted during the expedition, at depths from 32 to $292 \mathrm{~m}$.

133 Although numerous benthic organisms were observed (e.g., amphipods, soft corals, brittle stars,

134 bryozoans) fishes were not common. Five fish taxa were observed during drop-cam surveys, with

135 Polar cod the most common, occurring in $37.5 \%$ of the camera drops. Observations of Polar cod

136 ranged from 125 to $392 \mathrm{~m}$ and averaged 0.75 individuals per drop, with $\mathrm{N}_{\max }=6$ in any given

137 frame. The cottid, Iselus bicornis was present on three drops (16.7\%) with $\mathrm{N}_{\max }=3$, and depths

138 ranging from 58 to $132 \mathrm{~m}$. Another cottid, Artediellus scaber, was observed on two drops with $139 \mathrm{~N}_{\max }=4$ at depths of 281 to $392 \mathrm{~m}$. A single individual of an unidentified species, likely Capelin,

140 Mallotus villosus, was observed twice; once at Torup I. (296 m) and once at Bell I. (121 m), but

141 was not included in our species list due to taxonomic uncertainty. The most interesting sighting

142 was one large ( $>2 \mathrm{~m}$ ) Greenland shark (Somniosus microcephalus), which was observed off of

143 Hayes Island on 13.08 .2013 in $211 \mathrm{~m}$.

\section{Species accounts}

145 Family Somniosidae - Sleeper Sharks

146 Somniosus microcephalus (Bloch et Schneider, 1801) - Greenland shark (Fig. 2)

147 One $2 \mathrm{~m}$ specimen was recorded on drop camera off Hayes Island in $211 \mathrm{~m}\left(80^{\circ} 38.4 \mathrm{~N}, 58^{\circ} 08.4\right.$

148 E). This species was previously not known to occur around FJL (Dolgov, 2011; Wienerhoiter et

149 al., 2011). This sighting therefore represents the first record of a Greenland shark from FJL and is

150 the most north-eastern record for this species.

151 Family Gadidae - codfishes

152 Boreogadus saida (Lepechin, 1774) - Polar cod (Fig. 3) 
153 Polar cod are common at FJL and were recorded at 9 islands at depths ranging from 6-21 m.

154 Additional observations were made on drop cameras ranging in depth from 125 to $392 \mathrm{~m}$. Polar

155 cod occurred on 33\% the drop-cam deployments, averaging 0.75 individuals per frame, with a

156 maximum of 6 in any given frame.

157 MC: ZIN 6-013/7, length TL 64 mm, Prince Rudolf I., Cape Fligeli, 8150.92 N, 59¹5.77 E, 158 19.08.2013, dp 6-21 m; habitat - stones, sand; coll. O.V. Savinkin, A.N. Chichaev. - ZIN 6159 013/19, female TL 151 mm, 14.08.2013, Cape Podgorniy, Alger I., found on beach; coll. M.V.

160 Gavrilo. VO: TL 160 mm, Hayes I., 80³7.82 N, 5803.29 E, 12.08.2013, dp $11 \mathrm{~m}$,

161 A. Friedlander. DC: observed on 8 of 24 camera drops at Algers (392 m), Hayes (171-211 m),

162 Komsomolski (125 m), Kuhn (132 m), Luigi (357 m), Nansen (215 m), and Torup (297 m).

163

164 Polar cod were mentioned in FJL by numerous researchers dating back to the earliest expeditions

165 (Payer, 1878; Jackson, 1899; Nansen et al., 1900; Collett \&Nansen, 1899; Knipowitch, 1901).

166 Workers at the Tikhaya Bay Hydro-Meteorological station on Hooker Island $\left(80.3^{\circ} \mathrm{N}, 52.8^{\circ} \mathrm{E}\right)$ in

167 1931-32 regularly observed polar cod, most often during ice-hummock formation (Burmakin,

168 1957). Explosives were used to collect these fishes at $10-15 \mathrm{~m}$, resulting in $>100$ fish per blast

169 event. In the summer of 1975 and 1979, the staff of the Hydro-Meteorological station at Hayes

170 Island observed schools of polar cod "so large that they were scooped up by hand net" (Borkin,

171 1983). PINRO expeditions found polar cod common south-east of the archipelago at depths of

172 170-460 m (Borkin, 1993). Other sources state that polar cod occur north towards the North Pole

173 among the ice pack (Andriashev, Mukhomediyarov \& Pavshtiks, 1980; Mel'nikov \& Chernova,

174 2013a; Mel'nikov \& Chernova, 2013b).

175 Gadus morhua Linnaeus, 1758 - Atlantic cod

176 One Atlantic cod were collected. MC: ZIN 6-013/22, TL 200 mm, Alexandra Land, 8042.58 N,

$17747^{\circ} 31.55$ E, 28.08.2013; dp 15 m, habitat - rocks, coll. A. Friedlander.

178 Previously, one cod larva (18 mm TL) was collected 28.08.1980 south-east of FJL (7943' N, $17946^{\circ} 28^{\prime} \mathrm{E}$ ) by plankton net at 310-340 m; water temperature $=-0.4^{\circ} \mathrm{C}$ (Borkin, 1993). Adult cod 180 were found south-west of FJL during the Russian-Norwegian Cooperation Program from 20041812009 (Wienerroither et al., 2011). 
182 Family Cottidae - Sculpins

183 Icelus bicornis (Reinhardt, 1840) - Twohorn sculpin (Fig. 4)

184 Individuals were recorded at 8 islands between 7-21 m.

185 MC: 8 specimens TL 30-95 mm from 5 stations; ZIN 6-013/2, juv. TL $32 \mathrm{~mm}$, Hooker I., $18680^{\circ} 19.14$ N, 5248.66 E, 02.08.2013, dp 20 m; coll. A. Friedlander. - ZIN 6-013/5, female TL 48 187 mm, Kuhn I., 81¹0.46 N, 58²1.12 E, 09.08.2013, coll. O.V. Savinkin. - ZIN 6-013/6, female TL $18895 \mathrm{~mm}$ and 3 juv. TL 32-61 mm, Alexandra Land, 80 $42.57 \mathrm{~N}, 47^{\circ} 31.55 \mathrm{E}, 28.08 .2013$; ground 189 stones; dp 15m. - ZIN 6-013/24, juv. TL 30 mm, Wilton I. (at the entrance to Esipov Bay on 190 Nansen I.), $81^{\circ} 34.5$ N, 54⒚9 E, 23.08.2013, st 31, dp 6-21 m, ground - boulders, stones, sand; 191 coll. A.N. Chichaev. - ZIN 6-013/28, juv. TL 36 mm, Scott-Keltie I., 81²1.3 N 52²6.0 E, 192 27.08.2013, dp 17 m; ground - sand; coll. A. Friedlander. VO: length to $130 \mathrm{~mm}$, dp 7-15 m, A. 193 Friedlander. 1 sp, Northbrook I., Cape Flora, $79^{\circ} 57.43$ N, 5002.67 E, 05.08.2013. - 1 sp, Brosh 194 I., $81^{\circ} 06.27$ N, $58^{\circ} 21.01$ E, 08.08.2013. - 3 sp, Kuhn I., 810ㅜ 06.68 N, $58^{\circ} 19.78$ E, 16.08.2013. - 1 195 sp, Komsomol I., 80³8.82 N, 5855.05 E, 17.08.2013.

196 The species is common at FJL. Fish were observed mainly in rocky areas, mixed with sand, 197 boulders and shells, and water temperature $<0^{\circ} \mathrm{C}$. Underwater observations show fish usually 198 sitting on the bottom, perched atop widely spaced pectoral fins. A mottled disaggregated color 199 provides camouflage over mixed bottoms.

200 Artediellus scaber Knipowitch, 1907 - Hamecon (Fig. 5)

201 The species was found at 9 islands between 6-21 m.

202 MC: 9 specimens TL 31-75 mm. ZIN 6-013/14, TL 43 mm, Luigi I., 8052.5 N, $54^{\circ} 41.7$ E, 203 06.08.2013, dp 10 m. - ZIN 6-013/8, TL 62 mm, Prince Rudolf I., Cape Fligeli; 8150.92 N, $20459^{\circ} 15.77$ E, 19.08.2013, dp 6-21 m; ground - small stones, sand; st 28, coll. O.V. Savinkin, A.N. 205 Chichaev. - ZIN 6-013/16, TL 66 mm, Wilton I., 80³4.16 N, 54¹7.84 E; 23.08.2013, dp 17 m; 206 ground - rock; coll. A. Friedlander. - ZIN 6-013/17, juv. SL 28 mm, Alger I., 80²2.79 N, $20753^{\circ} 46.18$ E, 14.08.2013, dp 12-22 m; ground - sand; st 18, coll. O.V. Savinkin. - ZIN 6-013/18, 
208 juv. TL $31 \mathrm{~mm}$, Zub I. near Bliss I., 80²2.3 N, 54³9.6 E, 24.08.2013, dp 11 m; ground - sand; 209 st 32, coll. A.N. Chichaev, - ZIN 6-013/20, TL 75 mm, Kuhn I., $81^{\circ} 10.46$ N, $58^{\circ} 21.12$ E;

210 09.08.2013, coll. O.V. Savinkin. - ZIN 6-013/23, TL 73 mm, Wilton I., 81³4.5 N, $54^{\circ} 19.9$ E;

211 23.08.2013; st 31, dp 6-21 m; ground - boulders, stones, sand, coll. A.N. Chichaev. - ZIN 6-

$212013 / 27$, juv. TL 28 mm, Scott-Keltie, 81²1.3 N, 52²6.0 E, 27.08.2013, dp 17 m; ground - sand;

213 coll. A. Friedlander. - ZIN 6-013/29, TL 69 mm, Prince Rudolf I., Teplitz Bay, 81ํ4 N, $51^{\circ} 55$ E, 214 18.08.2013, dp 15-18 m, ground - boulders, sand; st 25, coll. S.D. Grebelniy. VO: 1 sp, Matilda 215 I., 80²1.92 N, 55²44.33 E, 14.08.2013, 15 m, A. Friedlander. - 1 sp, Bliss I., 24.08.2013, O.V. 216 Savinkin.

217 The Hamecon was a common inshore species and appeared to be highly site attached among 218 rocks and boulders. A variegated color pattern was observed in mixed sand and rocky habitat. 219 Hamecon were found in habitats ranging from the shallow red algae zone at Bliss Island to 220 deeper (8-20 m) Laminaria spp. beds off Prince Rudolf Island (pers. comm., S.D. Grebelniy, 221 2014).

222 Triglops nybelini - Bigeye sculpin

223 One fish was identified by a photograph taken 20.08 .2013 by M.V. Gavrilo at Torup I. (Fig. 6).

224 The fish, ca. $15 \mathrm{~cm}$ TL, was in the mouth of a Black guillemot Cepphus grylle (family Alcidae).

225 It was identified as a Bigeye sculpin, Triglops nybelini, based on its elongated body, wide

226 pectoral fins, cottoid-like shape, and a line of black spots above the anal-fin base.

227 Bigeye sculpin are frequently caught in trawls around FJL, primarily over silty sand in 100-500 228 m (Knipowitch, 1901; Andriashev, 1964). Hundreds of young-of-year (age 0+, 60-112 mm) were 229 caught by pelagic trawl west of FJL (Borkin, 1993). The presence of two other Triglops species 230 around FJL (T. murrayi and T. pingelii) (Wienerroither et al., 2011) need to be verified.

231 Family Cyclopteridae - Lumpfishes

232 Eumicrotremus spinosus (Fabricius, 1776) - Atlantic spiny lumpsucker (Fig. 7)

233 Specimens were recorded at 3 islands at depths from 8-15 m. 
234 MC: 1 sp TL 31 mm, Matilda I. (opposite Alger I.), 80²1.92 N, 5544.33 E, 14.08.2013, dp 8-15

235 m; A. Friedlander. VO: adult, Wilton I., 23.08.2013, photo: O.V. Savinkin; - adult, Bliss I.,

236 24.08.2013, photo in aquarium: A.P. Kamenev; - juv., 24.08.2013, same location, photo:

237 A. Friedlander.

238 Adult fish were observed adhering to rocks using ventral disks, juveniles were found sitting on

239 thalli of Laminaria spp. kelp. Previously, this species was recorded in FJL at $79^{\circ} 55 \mathrm{~N}, 49^{\circ} 48 \mathrm{E}$,

240 27.07.1901, in $34 \mathrm{~m}$ over shell habitat (Knipowitch, 1901), and also found west of Alexandra

241 Land (Wienerroither et al., 2011).

242 Eumicrotremus derjugini Popov, 1926 - Derjugin's leatherfin lumpsucker (Fig. 8)

243 Specimens were collected at Prince Rudlof and Zub islands at 6-21 m.

244 MC: ZIN 6-013/10, juv. TL 14 mm, Prince Rudolf I., Cape Fligeli, 8150.92 N, 59¹5.77 E,

245 19.08.2013, dp 6-21 m; ground - small stones, sand; st 28, coll. O.V. Savinkin, S.D. Grebelniy.

246 VO. Young, 24.08.2013, Zub I., photo: O.V. Savinkin.

247 Eumicrotremus derjugini differs from E. spinosus by having the first dorsal fin hidden in thick

248 fleshy leather; spiny plates on the body are smaller; enlarged plates in front of the anal fin origin

249 and along the first dorsal fin are absent; transversal skin folds between ventral sucking disk and

250 anus are absent; barbels on chin are absent. In young fish, spiny plates are less developed than in

251 adults. Previously a single juvenile was recorded from a trawl $\left(79^{\circ} 46^{\prime} \mathrm{N}, 63^{\circ} 08^{\prime} \mathrm{E}\right)$ at $240 \mathrm{~m}$

252 (Borkin, 1983; Borkin, 1993).

253 Cyclopteropsis mcalpini - McAlpin's smooth lumpfish (Fig. 9)

254 An adult Cyclopteropsis mcalpini ca. $40 \mathrm{~mm}$ LT was observed sitting on the empty shell of the

255 Gastropod Neptunea sp., with its egg mass inside the shell. This shell was collected between

256 Torup and Howen islands at $81^{\circ} 31$ N, $58^{\circ} 31.7$ E, 20.08.2013, st 29, dp 18-31 m, habitat - rock, 257 stones, sand, shells; coll. O.V. Savinkin. 
258 Forehead is wide and flattened, mouth is up turned; a row of 4 small spiny plates present on body 259 sides; color is pale with dark brown irregular net-like spots. The eggs, ca. $6 \mathrm{~mm}$ in diameter, had 260 well developed larvae that were nearly ready to hatch. Andriashev (1954) noted parental care in

261 Cyclopteropsis when a male was found on an empty gastropod shell protecting juveniles.

262 Family Liparidae - Snailfishes

263 Liparis bathyarcticus Parr, 1931 - Parr's snailfish (Fig. 10)

264 MC: 5 specimens from 2 stations; ZIN 6-013/3, TL 41 mm, Hayes I., 80³7.63 N, $58^{\circ} 03.88$ E, 265 13.08.2013, dp 8 m; coll. A. Friedlander. - ZIN 6-013/33, 5 juv. TL 15-16 mm, Pioneer I., $26680^{\circ} 38.82$ N, $58^{\circ} 55.05$ E, 17.08.2013, dp 15 m; st 22; coll. A. Friedlander. VO: 2 specimens at 267 Hayes I., Cape Druzhniy, 80³7.64 N, 5804.104 E, 13.08.2013, dp 6-1.5 m.

268 Parr's snailfish (ZIN 6-013/3) were found at $8 \mathrm{~m}$, in rocky habitat with gravel and clay. A pair 269 was observed sitting in a hole between rocks among small brown and green algae, at 1.5-6 m.

270 Larval L. bathyarcticus were observed 17.08.2013 in large numbers at 10-15 m at Pioneer Island.

271 Densities were as high as $10 \mathrm{~s} \mathrm{~m}^{-2}$. Similar densities were observed on nearby Kuhn Island

272 between 6-10 m on 16.08.2013 (A. Friedlander). Mean length of larvae was $13 \mathrm{~mm}(\mathrm{n}=12)$ and

273 were without pigment.

274 Early stage juveniles (TL 15-16 mm; egg sack still present; sucking disk entirely developed) were 275 present in our samples. The gill slit is as in adults, large and reaching down to mid-base of 276 pectoral fin upper lobe (in other arctic snailfishes it only extends from the $1^{\text {st }}$ to $6^{\text {th }}$ pectoral fin 277 ray). The name L. bathyarcticus was revalidated (Chernova, 2008). Adults feed partly on fishes.

278 Liparis tunucatus Reinhardt, 1837 - kelp snailfish (Fig. 11)

279 We recorded twelve specimens (TL 46-166 mm) at four islands between 6-30 m.

280 MC: ZIN 6-013/9, female TL 137 mm, Prince Rudolf I., Cape Fligeli, 8150.92 N, 59¹5.77 E, 281 19.08.2013, dp 6-21 m; ground - small stones, sand; st 28, coll. O.V. Savinkin, A.N. Chichaev. 282 ZIN 6-013/12, juv. TL 46 mm, Prince Rudolf I., 8151.09 N, 59²14.76 E, 19.08.2013, dp 15 m, 
283 coll. A. Friedlander. - ZIN 6-013/11, male TL 145 mm, and 3 sp, length 105-109 mm; Stolichki I., 284 eastward of Milovzorov rocks, 81⒒91 N, 58¹1.46 E, 08.08.2013; dp 6 m; coll. A. Friedlander. 285 VO: 6 sp, length to 166 mm, A. Friedlander. 3 sp, Prince Rudolf I., 8151.09 N, $59^{\circ} 14.76$ E, 286 19.08.2013, dp 15 m. - 2 sp, Howen I., 81³0.95 N, 58²1.41 E, 20.08.2013, dp 15 m. -1 sp., 287 Nansen I., 80³4.16 N, 54²17.84 E, 23.08.2013, dp $30 \mathrm{~m}$.

288 Kelp snailfish are common at FJL. Divers in 1981-1982 collected 47 specimens from 24 localities 289 at 1-32 m (Chernova, 1989a; Chernova, 1989b; Chernova, 1993). Fish were dark red and usually 290 attached to lower surface of kelp thalli, or under rock using their sucking disks. Spawning is 291 known to occur in March, and previous underwater observations found blackish-green egg 292 clutches on kelp thalli at 6 to $25 \mathrm{~m}$ during this time.

293 Liparis cf. fabricii Krøyer, 1847 - Blackbelly snailfish (Fig. 12)

294 Specimens were found by divers at 6 islands between 10-25 m; fry SL 31-83 mm were collected 295 by plankton net between $142-400 \mathrm{~m}$.

296 MC: 5 sp TL to 165 mm; ZIN 6-013/13, male TL 165 mm, Luigi I., Burke Bay, 8151.72 N, $29754^{\circ} 47.30$ E, 6.08.2013, dp 20-25 m; ground - silty sand, stones, silt; fish sitting on Laminaria; 298 coll. A.N. Chichaev. - ZIN 6-013/25, TL 106 mm, Bell I., 8002.29 N, $49^{\circ} 11.75$ E, 21.08.2013, 299 dp 17-22 m; ground - sand; coll. O.V. Savinkin. - ZIN 6-013/26, 2 sp TL 72 mm, Prince Rudolf 300 I., 19.08.2013; plankton net between 200-340 m; coll. D.M. Martinova. - ZIN 6-013/32, 1 sp SL

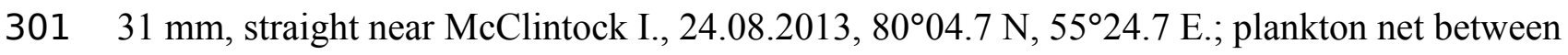
302 142-400 m; coll. A. Friedlander. VO (O.V. Savinkin): young specimen, Mabel I., 25.08.2013; 303 juv, Hooker I. at Rubini Rock, 1-2.08.2013.

304 The blackbelly snailfish Liparis fabricii is a species complex, which differs from other Arctic 305 snailfishes by having a black peritoneum (i.e., wall of body cavity) (Chernova, 2008).

306 The form from FJL collected by our expedition had a rounded head (head width is equal to head 307 depth) and a tapered snout with a prominent point. The posterior nostril is half the size of the 308 anterior nostril, without flap-like projections. The mouth is horizontal with small anterior teeth, 309 jaws are trilobate, posterior teeth have small lateral shoulders. Snout folds are undeveloped, 310 opercular flaps are rounded. Gill slits reach to 5-8th pectoral rays. Some anterior dorsal fin rays 
311 are shorter than posterior rays. The upper pectoral fin lobes reach slightly behind the anal fin

312 origin. The disk is well developed and the skin of adult males is covered by cone-like prickles.

313 Vertebrae 50-53 (11+39-42); D 44-49, A 37-41; P 36 (28+8). Caudal fin includes 9-10 principal

314 rays, 2 upper and 2 lower secondary rays. Color is blackish with small black spots; between 3 and

3155 wide oblique bands present at dorsal and anal fins. Peritoneum black after preservation, without

316 silvery pigmentation.

317 Pelagic young have a dark band along dorsal fin base; dorsal and anal fins are semi-transparent, 318 with 5 and 3 transversal blackish spots, respectively; peritoneum is black and distinctly visible 319 through body wall, masked from outside by silvery guanine pigmentation that quickly disappears 320 after preservation in formaldehyde.

321 Underwater observation shows adults close to bottom, among thalli of kelp, at a depth 10-25 m;

322 ground - silty sand with stones, overgrown by algae (mainly Sacharina latissima and Alaria 323 esculenta).

324 Blackbelly snailfish are common at FJL. Divers from the MMBI expedition collected 20

325 specimens at 13 locations (Chernova, 1993). Based on PINRO surveys, L. fabricii likely school, 326 with $>500$ specimens caught in a one hour trawl; aggregations of young in pelagic trawls $(0+$,

327100 s of specimens) were recorded westward of FJL, at $81^{\circ} 04 \mathrm{~N}, 43^{\circ} 18 \mathrm{E}$ (Borkin, 1993).

328 Family Agonidae - Sea Poachers

329 Leptagonus decagonus (Bloch et Schneider, 1801) - Atlantic poacher

330 One Atlantic poacher, TL $180 \mathrm{~mm}$, was identified from Brosh Island $\left(81^{\circ} 06.28 \mathrm{~N}, 58^{\circ} 21.19 \mathrm{E}\right)$,

331 08.09.2013, at $10 \mathrm{~m}$ (identification: A. Friedlander). Leptagonus decagonus $(16-21 \mathrm{~cm})$ were 332 collected at FJL by PINRO surveys at 245-400 m (Borkin, 1993), and also south of Alexandra

333 Land (Wienerroither et al., 2011).

334 Family Zoarcidae - Eelpouts

335 Lycodes reticulatus Reinhardt, 1835 - Arctic eelpout (Fig. 13) 
336 Three specimens between 180-248 $\mathrm{mm}$ TL were recorded at depths from 6-15 m sheltering in

337 rocky areas among kelp (identification: A. Friedlander): Brosh I., 8106.26 N, $58^{\circ} 21.15$ E,

338 16.08.2013, dp 15 m. - Hayes I., 80³7.82 N, 5803.29 E, 12.08.2013, dp 6 m. - Howen I.,

$33981^{\circ} 30.95$ N, $58^{\circ} 21.41$ E, 20.08 2013, dp 15 m. Previously specimens were collected from

340 Alexandra Land at $124 \mathrm{~m}$ (Andriashev, 1964), and south of the archipelago between 180-410 m

341 (Borkin, 1993; Wienerroither et al., 2011).

342 Gymnelus andersoni Chernova, 1998 - Anderson's pout (Fig. 14)

343 One specimen was found on the deck of the ship partially digested and likely deposited by a

344 seabird (caudal portion missing). The specimen has infraorbital pores absent; the origin of the

345 dorsal fin was near vertical of the anal-fin origin; pre-dorsal distance (from tip of snout to dorsal

346 fin origin) is $205 \%$ of head length (lc). Radiogram counts: abdominal vertebrae 21 . The first ray

347 of D-fin located between vertebrae 14 and 15; 11 interneuralia bear no corresponding dorsal fin

348 ray, the first is between vertebrae 4 and 5. Head depressed. Pectoral fin length 57.5\% lc. Pectoral-

349 fin rays 10.

350 MC: ZIN 6-013/1, male TL 120 mm, Hooker I., Tikhaya Bay, 80¹9,39 N, 5250,87 E, 4.9.2013.

351 Anderson's pout differs from G. viridis by the posterior position of dorsal fin origin, with the pre352 dorsal distance 2x longer than the head length. Gymnelus andersoni differs from G. retrodorsalis

353 (with similar position of dorsal fin origin) by having reduced sensory pores in the infraorbital

354 canal (pores below eye are closed or entirely absent) (Chernova, 1998a; Chernova, 1998b).

355 Paratypes of $G$. andersoni derive south-east of FJL $\left(77^{\circ} 31 \mathrm{~N}, 64^{\circ} 34 \mathrm{E}\right)$ at depth $280 \mathrm{~m}$ (ZIN 356 14160).

357 Gymnelus esipovi Chernova, 1999 - Esipov’s pout (Fig. 15)

358 MC: ZIN 6-013/4, male TL 141 mm, Wilton I., 80³4.16 N, 54²17.84 E, 23.08.2013, dp 15 m, 359 habitat - rock; collected in kelp by A. Friedlander. 
360 Gymnelus esipovi differs from G. andersoni in its anterior dorsal fin position (pre-dorsal distance

$361<1.3$ larger than head); infraorbital pores are well developed. This species was previously known

362 only from Spitsbergen, the northern Barents Sea near Novaya Zemlya $\left(75^{\circ} 53-76^{\circ} 30\right.$ N, $51^{\circ} 55-57$

363 E), and the northern Kara Sea (Chernova, 1999a). This is the first record of Gymnelus esipovi

364 from FJL.

365 DISCUSSION

\section{FJL fish fauna diversity}

367 Our expedition identified 16 species of fishes from 7 families mainly in nearshore FJL $(<34 \mathrm{~m})$.

368 We added two species previously unknown for FJL; the Greenland shark (Hayes Island, $211 \mathrm{~m}$ )

369 and Esipov's pout (Wilton Island, $15 \mathrm{~m}$ ). For many other species, our expedition increased the

370 numbers of localities within the archipelago where these species are known, as well as identifying

371 new upper depth limits for many species. The only nearshore fish species previously recorded

372 from the archipelago but not found during our expedition was the tape-body pout Gymnelus

373 taeniatus, which is likely locally endemic to Franz Josef Land (Chernova, 1999a).

374 Most of the trophic diversity is comprised of invertebrate feeders, while three species (Greenland

375 shark, Atlantic cod, and Parr's snailfish) are facultative piscivorous. However the vast majority of

376 the fish biomass for the region is likely polar cod, which can feed on zooplankton under the ice.

377 The low observed abundance of this species may be explained by the lack of sea ice near FJL

378 during our expedition.

379 Species endemic to the Arctic accounted for three quarters of the nearshore species, the majority

380 of which are common at high latitudes and circumpolar in the Arctic (Chernova, 2011). The

381 distribution of some species (e.g., Arctic eelpout, Anderson's pout, Esipov's pout, and McAlpin's

382 smooth lumpfish) is currently not fully known. The presence of larvae and young-of-year of

383 many of the nearshore fishes suggests as least some local spawning and self-recruitment. The

384 nearshore waters around FJL are important as nursery habitat for a number of fishes found in

385 deeper water. 
386 Compared with much of the Barents Sea, the fish fauna of FJL is depauperate. The waters around

387 FJL are at or below freezing year round and the littoral zone is covered by ice during much of the 388 year. As a result, nearshore fishes are restricted to a zone between 6 and $25 \mathrm{~m}$, in areas dominated 389 mainly by macrophytes.

390 Several species may only spend a portion of their lives in FJL. The Greenland shark $S$.

391 microcephalus is nomadic. FJL is not recognized as a nursery or feeding area for young Atlantic

392 cod and capelin, but favorable currents and oceanographic conditions may allow these species to

393 survive until they migrate to spawning areas towards the south and west. The Arctic cod,

394 Arctogadus glacialis, is a cryopelagic (sympagic) species that occurs south of FJL, as well as

395 northward to the North Pole (Andriashev \& Chernova, 1994; Chernova, 2011). The lack of pack

396 ice around FJL during our expedition may account for the absence of this species from our list.

397 Some mesopelagic fishes are also non-residents. Glacier Lanternfish Benthosema glaciale and

398 White Barracudina Arctozenus risso occur south and west of the archipelago, but the extreme

399 environment conditions of FJL likely prevent these species from reproducing in these waters.

400 Many of the other species that are known from FJL occur in $>34 \mathrm{~m}$ and therefore not

401 encountered on our surveys.

402 Trawl catches around FJL in depths 100-600 $\mathrm{m}$ have recorded 43 fish species from 15 families.

403 Most are primarily demersal, non-migrating species with the exception of the commercially

404 important black halibut, which spawns on the western continental slope of the Barents Sea.

405 Nursery and feeding areas for black halibut occur west of FJL in the Franz Victoria Trough, as

406 well as Voronin and St. Anna troughs to the east. With the exception of black halibut, there are

407 currently no fish species in commercially-exploitable abundance around FJL.

408 Abundance of FJL fishes

409 Notes published from the Jackson-Harmsworth Expedition of 1894-97 state: "Though angling

410 with line and hook was tried, it proved unsuccessful; and in order to obtain specimens of fish, it

411 became necessary to stand on the shore and wait for the birds that came flying in from the distant

412 open water with fish in their mouths. These birds were promptly shot, and came tumbling down

413 with the fish still in their grip. This is an instance, I fear, of highway robbery with violence to the

414 person, but science condones much." Later in the text they state: "Fishing with line met with no 
415 success, but many specimens were taken from birds, and are preserved and brought back." (Brice 416 \& Fisher, 1896).

417 Our results confirm that fishes in FJL are not abundant. The density of fishes observed during 418 dives was very low. On average, only a few individuals were observed on any dive $(\mathrm{N}=68)$.

419 These low densities likely reflect very low standing stock of benthic fishes, but also related to the 420 fact that many of the individuals were extremely cryptic, occurring on the underside of kelp 421 fronds or hiding within rocks and/or kelp holdfasts. Underwater visual surveys of fishes off West 422 Greenland yielded densities of 0.03 fishes $\mathrm{m}^{-2}$ (Gremillet et al., 2004) and are typical for other 423 Arctic rocky shores (Hoff, 2000; Born \& Böcher, 2001). Results of our beach seine efforts 424 confirm fish scarcity. In 56 hauls at 4 locations no fishes were collected and no fishes were 425 observed in this habitat. There was continuous daylight during the entire expedition so it is 426 unclear if the abundance patterns we observed are similar during other times of the year.

427 However due to sea ice conditions during the winter months, abundances are likely highest 428 during the summer period when our sampling was conducted.

429 The blood serum of most fishes freezes at $<-0.07^{\circ} \mathrm{C}$ (Holmes \& Donaldson, 1969) and therefore 430 the shallow water or extremely cold, ice-laden deep waters surrounding FJL are inhospitable for 431 most species. Fish that live in the polar oceans survive at low temperatures by virtue of 432 'antifreeze' plasma proteins in the blood that bind to ice crystals and prevent these crystals from 433 growing (Fletcher, Hew \& Davies, 2001, Marshall, Fletcher \& Davies, 2004). The blood of the 434 cryopelagic fishes, such as Notothenioids Pagothenia borchgrevinki and Dissostichus mawsoni 435 (Perciformes) in Antarctic and cod species B. saida and A. glacialis in the Arctic, contains 436 glycoproteins that serve as antifreeze agents.

437 No commercial fishing occurs in FJL due to extensive ice cover for most of the year and the 438 absence of commercially abundant fishes. The Atlantic cod, haddock, capelin, red-fishes, wolf 439 fishes, and flat fishes either are absent from FJL or occur at densities too low for commercial 440 exploitation. Polar cod are common in FJL waters, with enormous shoals sometimes observed, 441 but the low value of this species has precluded commercial exploitation. Polar cod are important 442 ecologically in high-Arctic areas. They are an essential link in the cryopelagic food web by 443 grazing on under-ice zooplankton and in turn are a major food component of many seabirds and 
444 marine mammals (Bradstreet et al., 1986; Finley, Bradstreet \& Miller, 1990; Welch, Crawford \&

445 Hop, 1993). Many questions on the biology and ecology of arctic fish still remain unanswered.

\section{Trends assuming climate change scenarios}

447 The climate projections for the eastern Arctic show a warming that will cause a shift from sea-ice 448 algae-benthos-dominated to zooplankton-dominated communities (Bates \& Mathis, 2009). Such

449 a fundamental shift may have negative consequences on large marine carnivores (e.g., seabirds 450 and marine mammals), but have a positive influence on the abundance of smaller carnivores (e.g., 451 fishes), because the average body size of prey will decrease substantially (Karnovsky et al., 452 2003).

453 Until recently, the north-eastern Barents Sea has had permanent ice-cover, but during the last 454 decade the entire shelf sea has been ice free during the summer months (Johannesen et al., 455 2012a). A retreat and thinning of the ice cover in the Barents Sea likely will result in the northern 456 portion becoming more Atlantic in character, with a higher productivity at the sea floor (Cochrane 457 et al., 2009). The northern fish fauna currently has low biomass, but a shift towards more 458 productive Atlantic water will likely result in an overall increase in benthic biomass to the north.

459 A northern shift in the penetration of Atlantic water will likely make the area more similar in 460 faunal structure and ecosystem function to the southern parts of the Barents Sea. The Barents Sea 461 today supports large commercial fisheries, and a potential climate-driven increase in their 462 harvestable areas is of high social and economic interest. Under warming conditions, trophic 463 interactions in the ecosystem could weaken as a result of increased diversity at each trophic level 464 caused by range expansion of species found in warmer areas. Cod larvae are spread by currents

465 from spawning grounds throughout the Barents Sea. As the waters around FJL warm, Atlantic cod 466 and other boreal and sub-Arctic species will likely become more abundant. The impact of 467 fisheries on the Arctic, which can be expected to increase, as industrial fisheries move into a 468 warming Arctic following the invasion of boreal species. The lack of basic knowledge regarding 469 fish biology and habitat interactions in the north, complicated by scaling issues and uncertainty in 470 future climate projections limits our preparedness to meet the challenges of climate change in the 471 Arctic with respect to fish and fisheries (Reist et al., 2006). 


\section{References}

474 Andriashev AP 1939. Essay of zoogeography and origin of the fish fauna of the Bering Sea and 475 neighboring waters. Leningrad State University Publishing House. 188 p. [In Russian].

476 Andriashev AP. 1954. Fishes of the Northern Seas of the USSR. Moscow-Leningrad: Academy of 477 Science Press, p. 1-567. [In Russian; English Translation. 1964. Israel Program of Scientific 478 Translations (836):1-617].Andriashev AP. 1964. The list of fishes collected by the expedition 479 onboard the ice-cutter F. Litke (1955) northward of Franz Josef Land and Spitsbergen. Trudy 480 Arcticheskogo i Antarcticheskogo N.I. In-ta, 259:373-377 [In Russian].

481 Andriashev AP, Chernova NV. 1994. Annotated list of fishlike vertebrates and fish of the Arctic 482 seas and adjacent waters.Voprosy Ikhtiol. 34:435-456. [In Russian, English Translation: Journal 483 of Ichthyology. 35:81-123].

484 Andriashev AP, Mukhomediyarov BF, Pavshtiks EA. 1980. On mass aggregations of cryopelagic 485 cod fishes (Boreogadus saida and Arctogadus glacialis) in the North-Pole areas of the 486 Arctic.Biology of the Central Arctic Basin. Moscow, Nauka Publishing House. P. 196-211. [In 487 Russian]

488 Barr S. 1994. Franz Josef Land. Norsk Polarinstitutt, Middelton gate 29, 0301, Oslo. 90 pp. 489 Bates NR, Mathis JT. 2009. The Arctic Ocean marine carbon cycle: evaluation of air-sea CO 2 490 exchanges, ocean acidification impacts and potential feedbacks. Biogeosciences 6:2433-2459. 491 Borkin IV. 1983. Results of fish-fauna study in the area of Franz Josef Land and northward of 492 Spitsbergen. Study of Biology, Morphology and Physiology of hydrobionts. Apatity, Kola 493 Branch of the AN USSR. P. 34-42. [In Russian]

494 Borkin IV. 1986. Record of Glacier lanternfish Benthosema glaciale in Franz Josef Land area. 495 Biologiya morya, No 3. P. 63-64. [In Russian]

496 Borkin IV. 1993. Fishes inhabiting coastal waters.Environment and ecosystems of the Franz Josef 497 Land (Archipelago and shelf). Apatity: Izd. Kolskogo nauch tsentra AN SSSR. P. 188-195. 498 Born EW, Böcher J. 2001. The Ecology of Greenland. Atuakkiorfik Education, Nuuk. 499 Bradstreet MSW, Finley KJ, Sekerak AD, et al. 1986. Aspects of the feeding biology of Arctic $500 \operatorname{cod}$ (Boreogadus saida) and its importance in Arctic marine food chains. Canadian Technical 501 Reports. Fisheries and Aquatic Science No. 1491. 193 p.

502 Brice AM, Fisher H. 1896. The Jackson-Harmsworth polar expedition, notes of the last year's 503 work. The Geographical Journal 8:543-564. 
504 Burmakin EV. 1957. Fishes of the Soviet Arctic islands.Trudy arktich. n.-i. in-ta. 205:127-151.

505 [In Russian]

506 Camerano L. 1903. Osservazioni intorno al "Gadus saida Lepechin”, della Baia di Teplitz.

507 Osservazioni scientifiche esequite durante la Spedizione polare di S.A.R. Luigi Amedeo di

508 Savoia duca degli Abruzzi, 1899-1900. Ulrico Hoepli, Editore-Librajo della real casa Milano.

509 Tipografia Del R. Istituto Idrografico, Genova. P. 609-620. [Separate, 12 p.]

510 Chernova NV. 1989. Snailfishes. Ecology and bio-resources of the Kara Sea. Apatity. Izd.

511 Kolskogo nauch tsentra AN SSSR. P. 104-120. [In Russian]

512 Chernova NV. 1991. Snailfishes of the Euro-Asian Arctic. - Apatity. Izd. Kolskogo nauch tsentra

513 AN SSSR. 111 p. [In Russian]

514 Chernova NV. 1993. Snailfishes. Pp. 195-197 Matishov G.G. et al. (eds). Environment and

515 ecosystems of Franz Josef Land (Archipelago and shelf). Assoc. of Authors. Apatyty. Kola

516 Sci.Centre, Rus. Acad. Sci Press. 262 pp.

517 Chernova NV. 1998a. A new species Gymnelus andersoni sp. nova, from the Arctic seas with re-

518 validation of the species status of G. retrodorsalis Le Danois and G. pauciporus Anderson

519 (Fam. Zoarcidae).Vopr. ichthyol. V. 38. No 6. P. 737-744. [In Russian. Engl. Transl.: J. Ichthyol.

520 38:737-744].

521 Chernova NV. 1998b. Reestablishment of the validity of species Gymnelus bilabrus Andriashev

5221937 with characteristics of species G. viridis verified (Fabricius, 1780) (Zoarcidae).Vopr.

523 ichthyol. 38:182-188. [In Russian. Engl. Transl.: Journal of Ichthyology 38:163-169].

524 Chernova NV. 1999a. Four new species of Gymnelus (Zoarcidae) from the Arctic region. Vopr.

525 ichthyol. 39: 306-315. [In Russian. Engl. Transl.: Journal of Ichthyology 39:343-352].

526 Chernova NV. 1999b. New species Gymnelus knipowitschi from the Arctic Ocean and a

527 redescription of G. hemifasciatus Andriashev (Zoarcidae). [In Russian. Engl. Transl.: Journal

528 of Ichthyology. 39:5-13].

529 Chernova NV. 2007. Fish fauna of Franz Josef Land and the northern part of Navaya

530 Zemlya.Modern studies of fish fauna of arctic and southern seas of European part of Russia.

531 Apatity: KNZ RAN. P. 55-74. [In Russian]

532 Chernova NV. 2008. Systematics and phylogeny of the genus Liparis (Liparidae,

533 Scorpaeniformes). Journal of Ichthyology (Supplement) 48:831-852.

534 Chernova NV. 2011. Distribution Patterns and Chorological Analysis of Fish Fauna of the Arctic 535 Region. Journal of Ichthyology 51:825-924. 
536 Cochrane SK, Denisenko SG, Renaud PE, Emblow CS, Ambrose WG Jr, Ellingsen IH,

537 Skarðhamar J. 2009. Benthic macrofauna and productivity regimes in the Barents Sea-

538 ecological implications in a changing Arctic. Journal of Sea Research 61:222-233.

539 Collett R, Nansen F. 1899. Account of birds. The Norwegian North Polar Expedition, 1893-1896.

540 Scientific Results. V.4. 54 pp.

541 Dolgov AV. 2011. Atlas and key for identification of fishes of the Barents Sea. Murmansk, izd-vo 542 PINRO, $187 \mathrm{p}$.

543 Dunbar MJ. 1968. Ecological development in Polar Regions: A study in evolution. Prentice-Hall, 544 New Jersey $199 \mathrm{p}$.

545 Esipov VK. 1931. Fishes collected by the expedition to Franz Josef Land in summer 1929.Trudy

546 in-ta po izuch. severa. V. 49. P. 156-165. [In Russian]

547 Esipov VK. 1933. Fishes, collected by the expedition of year 1930 on board of ice steamer G.

548 Sedov to Franz Josef Land and Severnaya Zemlya.Trudy Arktich. N.-I. In-ta. V. 8. P. 93-100.

549 [In Russian]

550 Finley KJ, Bradstreet MSW, Miller GW. 1990. Summer feeding ecology of harp seals (Phoca

551 groenlandicus) in relation to Arctic cod (Boreogadus saida) in the Canadian High Arctic. Polar

552 Biology 10:609-618.

553 Fletcher GL, Hew CL, Davies PL 2001. Antifreeze proteins of teleost fishes. Annual Review of

554 Physiology 63:359-390.

555 Fossheim M, Nilssen EM, Aschan M. 2006. Fish assemblages in the Barents Sea. Marine Biology

556 Research 2:260-269.

557 Gremillet D, Kuntz G, Delbar F, Mellet M, Kato A, Robin JP, Chaillon PE, Gendner JP,

558 Lorensten SH, Le Maho Y. 2004. Linking the foraging performance of a marine predator to

559 local prey abundance. Functional Ecology 18:793-801.

560 Hoff GR. 2000. Biology and ecology of threaded sculpin, Gymnocanthus pistilliger, in the

561 eastern Bering Sea. Fishery Bulletin 98:711-722.

562 Holmes WN, Donaldson EM. 1969. The Body Compartments and the Distribution of

563 Electrolytes. Fish Physiology 1:1-89.

564 Jackson FG. 1899. A Thousand Days in the Arctic. Harper \& Brothers, New York and London. V.

565 2. 580 p. (cited after: Camerano, 1903).

566 Johannesen E, Ingvaldsen R, Dalpadado P, Skern-Mauritzen M, Stiansen JE, et al. 2012a. Barents

567 Sea ecosystem state: climate fluctuations, human impact and trophic interactions. ICES Journal

568 of Marine Science. doi:10.1093/icesjms/fss046. 
569 Johannesen E, Høines ÅS, Dolgov AV, Fossheim M. 2012b. Demersal Fish Assemblages and

570 Spatial Diversity Patterns in the Arctic-Atlantic Transition Zone in the Barents Sea. PLoS ONE

571 7(4): e34924. doi:10.1371/journal.pone.0034924.

572 Karnovsky NJ, Kwasniewski S, Weslawski JM, Walkusz W, Beszczynska-Möller A. 2003.

573 Foraging behaviour of little auks in a heterogeneous environment. Marine Ecology Progress

574 Series 253:289-303.

575 Knipowitch N. 1901. Zoological study on board of ice-breaker Yermak in summer

576 1901.Ezhegodnik Zool. muzeya Inperat. Akad. Nauk. V. 6, No 2-3. P. I-XX. [In Russian]

577 Koltun VM. 1964. Hydrobiologic works of high-arctic expeditions on board of ice-breaker F.

578 Litke and diesel- electric vessels Ob' and Lena. Trudy Arktich. i Antarctich. N.-I. In-ta. V. 259.

579 P. 5-12. [In Russian]

580 Marshall CB, Fletcher GL, Davies PL. 2004. Hyperactive antifreeze protein in a fish. Nature $581 \quad 429: 153-153$.

582 Mecklenburg CW, Møller PR, Steinke D. 2010. Biodiversity of arctic marine fishes: taxonomy

583 and zoogeography. Marine Biodiversity DOI 10.1007/s12526-010-0070-z.

584 Mel'nikov A, Chernova NV. 2013a. Characteristics of under-ice swarming of polar cod

585 Boreogadus saida (Gadidae) in the central Arctic ocean.Voprosy Ichthyologii, V. 53. No. 1. P.

586 22-30. [In Russian. Engl. Translation: Journal of Ichthyology53:22-30.].

587 Mel'nikov IA, Chernova NV. 2013b. Under-ice swarming of polar cod in the North-Pole area.

588 Priroda, 1:49-53. [In Russian]

589 Nansen F, Johansen H, Nordahl B. 1900. Fra ghiacci e tenebre. La spedizione polare norvegese

590 1893-1896. Narrata da Fridtjof Nansen, seguita dalla relazione del Capitano del Fram Otto

591 Payer J. 1878. L'expedition du Tegetthoff. Voyage de découvertes aux $80^{\circ}-83^{\circ}$ degrés de latitude

592 Nord. Traduit de l'allemand par J. Gourdault. Parigi, Hachette et C. 381 pp. (cited after:

593 Camerano, 1903).

594 Reist JD, Wrona FJ, Prowse TD, Power M, Dempson JB, et. al. 2006. General effects of climate

595 change on Arctic fishes and fish populations. AMBIO 35:370-380.

596 Savin SM. 1977. The history of the Earth's surface temperature during the past 100 million years.

597 Annual Reviews of Earth and Planetary Sciences 5:319-355.

598 Schauer U, Loeng H, Rudels B, Ozhigin VK, Dieck W. 2002. Atlantic water flow through the

599 Barents and Kara Seas. Deep Sea Research Part I: Oceanographic Research Papers, 49:22816002298. 
601 Stiansen JE, Filin AA. (eds.), 2008. Joint PINRO/IMR report on the state of the Barents Sea 602 ecosystem in 2007, with expected situation and considerations for management. IMR-PINRO 603 Joint Report Series 2008(1), Institute of Marine Research, Bergen, Norway, 185 pp.

604 Stiansen JE, Korneev O, Titov O, Arneberg P. (Eds.), Filin, A., Hansen, J.R., Høines, Å., 605 Marasaev, S. (Co-eds.) 2009. Joint Norwegian-Russian environmental status 2008. Report on 606 the Barents Sea Ecosystem. Part II - Complete report. IMR/PINRO Joint Report Series, 607 2009(3), 375 pp. ISSN 1502-8828.

608 Svetovidov AN. 1948. Gadiformes. Fauna of the USSR. V. IX. No 4. Moscow-Leningrad, Izd-vo 609 Akad.Nauk SSSR. 224 p. [In Russian]

610 Wassmann P, Reigstad M, Haug T, Rudels B, Carroll ML, Hop H, Wing Gabrielsen G, Falk-

611 Petersen S, Denisenko SG, Arashkevich E, Slagstad D, Pavlova O. 2006. Food webs and carbon 612 flux in the Barents Sea. Progress in Oceanography 71:232-287.

613 Welch HE, Crawford RE, Hop H. 1993. Occurrence of Arctic Cod (Boreogadus saida) schools 614 and their vulnerability to predation in the Canadian High Arctic. Arctic 46:331-339.

615 Wienerroither R, Johannesen E, Dolgov A, Byrkjedal I, Bjelland O, et al. 2011. Atlas of the 616 Barents Sea Fishes. IMR/PINRO Joint Report Series 1-2011. ISSN 1502-8828. 273 p. 


\section{Table $\mathbf{1}$ (on next page)}

Species of fishes observed during expedition to Franz Joseph Land in summer 2013. 


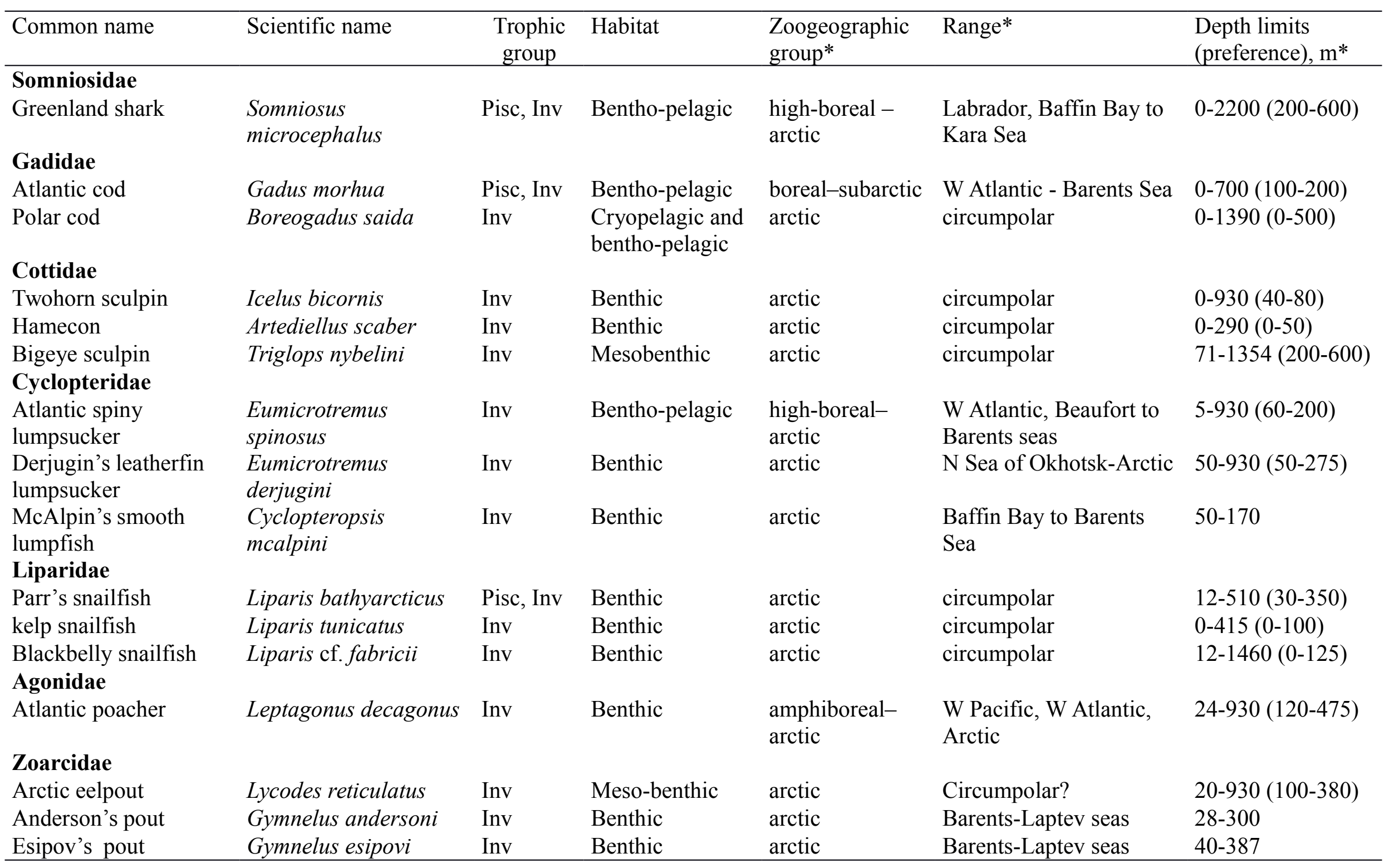


* After Chernova (2011); Pisc - piscivore, Inv - invertivore. 
Table 2 (on next page)

The number of fish orders, families, and species collected or observed in waters around Franz Josef Land during summer 2013. 


\begin{tabular}{llc}
\hline Order & Family & $\begin{array}{c}\text { Number } \\
\text { of species }\end{array}$ \\
\hline Squaliformes & Somniosidae & 1 \\
Gadiformes & Gadidae & 2 \\
Scorpaeniformes & Cottidae & 3 \\
& Agonidae & 1 \\
& Cyclopteridae & 3 \\
& Liparidae & 3 \\
& Zoarcidae & 3 \\
\hline
\end{tabular}


1

Franz Joseph Land with names of islands where collections were conducted during the expedition. 


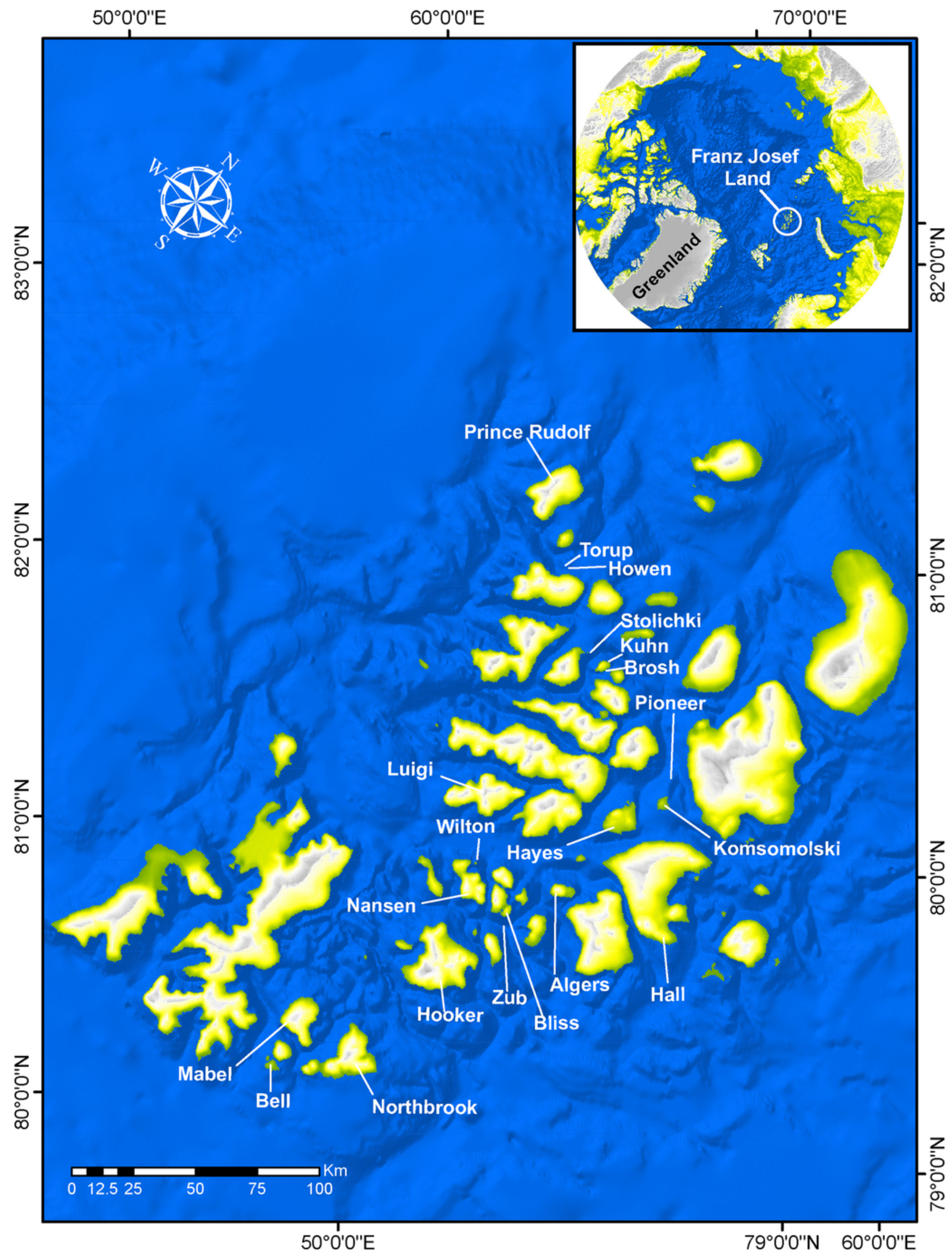


2

Greenland shark, Somniosus microcephalus, off Hayes Island in $211 \mathrm{~m}$.

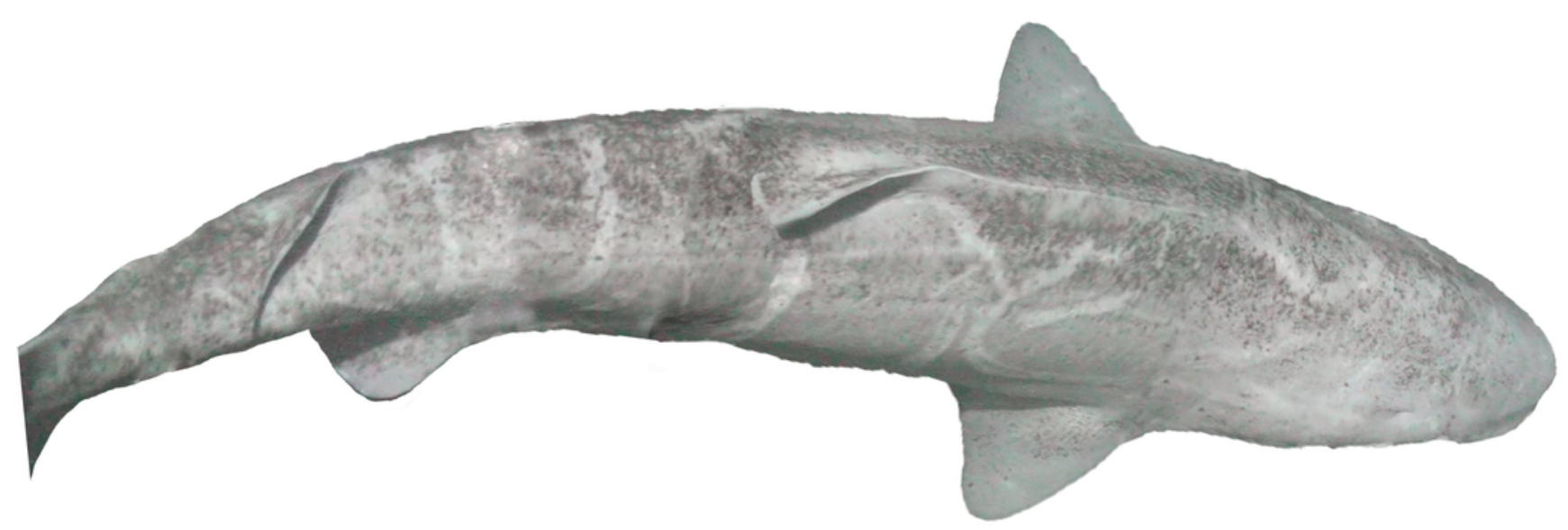




\section{3}

Polar cod, Boreogadus saida, TL 64 mm; Prince Rudolf Island.

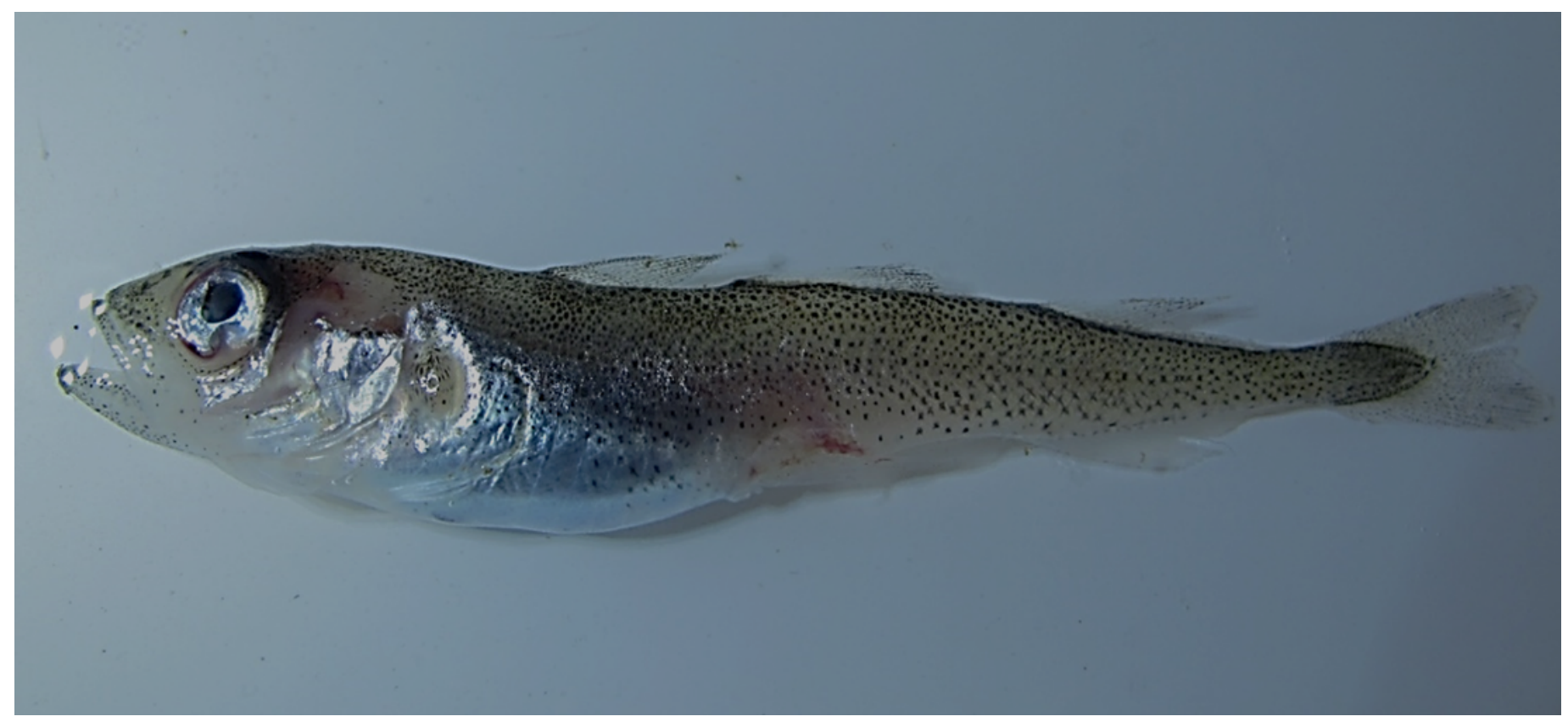




\section{4}

Twohorn sculpin, Icelus bicornis.

A - Young, Wilton Island; color is mottled, with dark brown spots and yellow strips with pale background. A large triangular spot is present below the first dorsal fin, with 4 small rounded spots are found below the second dorsal fin. Dark bands radiate around eye; fin rays locally yellow; a round brown spot is present on the base of pectoral fin. B - Juvenile TL $34 \mathrm{~mm}$, Hooker Island, ZIN 6-013/2. C - Occipital thorns of hind pair are visible at nape, directed backward; narrow pale strip is present behind head, wide brown spot narrowing downward is present below the first dorsal fin. D - Adult male, Kuhn Island, ZIN 6-013/5; dorsal and anal fins are enlarged, bright orange and white bands are intermittent at anal and caudal fins (sexual dimorphism). 

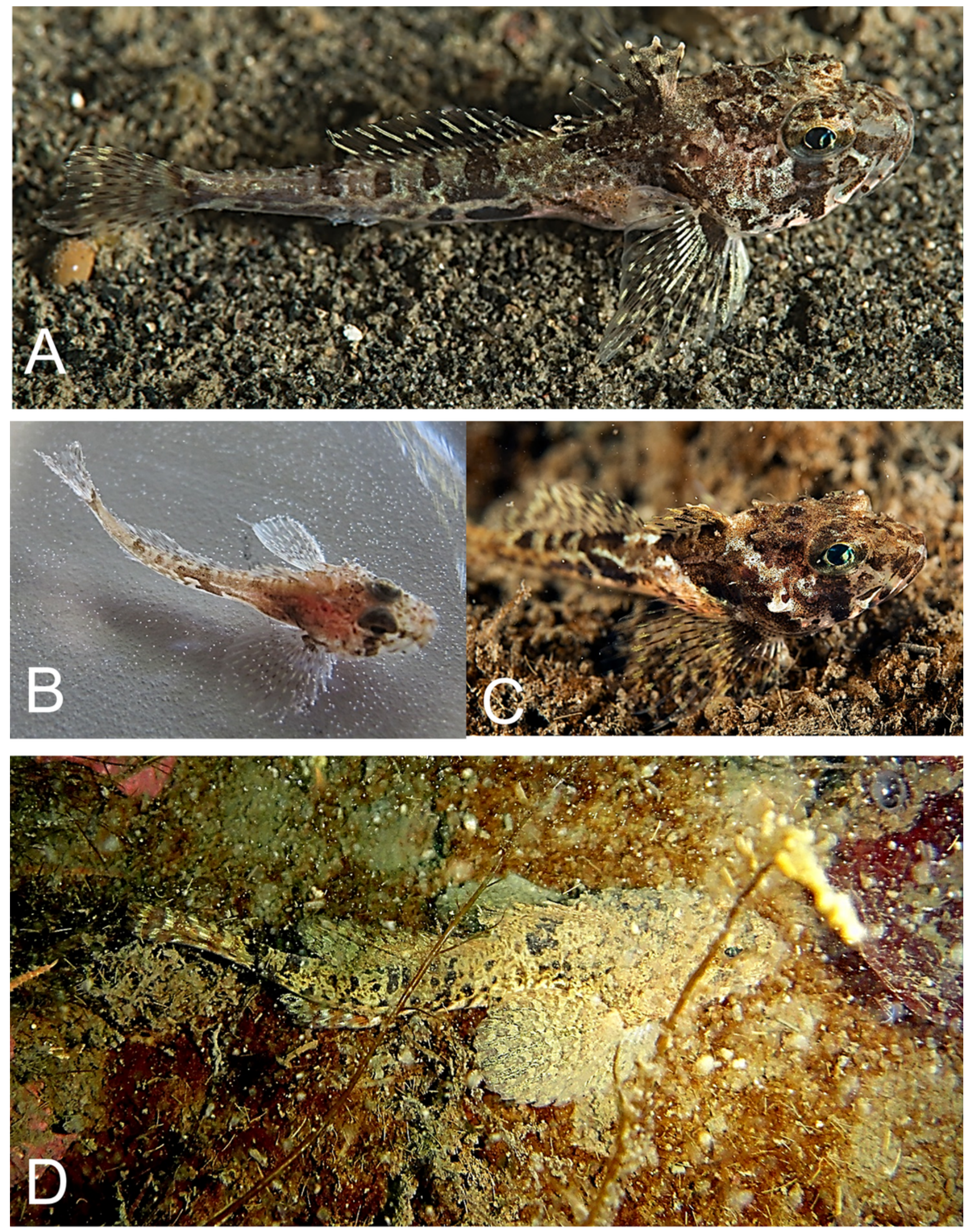


\section{5}

Hamecon, Artediellus scaber.

A - Female TL 69 mm, ZIN 6-013/29, preserved specimen; nape behind eyes is depressed, occipital thorns not expressed. B - Specimen is sitting near rock within area of macroalgae. C

- Mottled color camouflages fish on sandy-pebble bottom. D - Hamecon feeding on peryphiton with sea urchin present in front; Bliss I. E - Hamecon among red algae; Bliss I. 

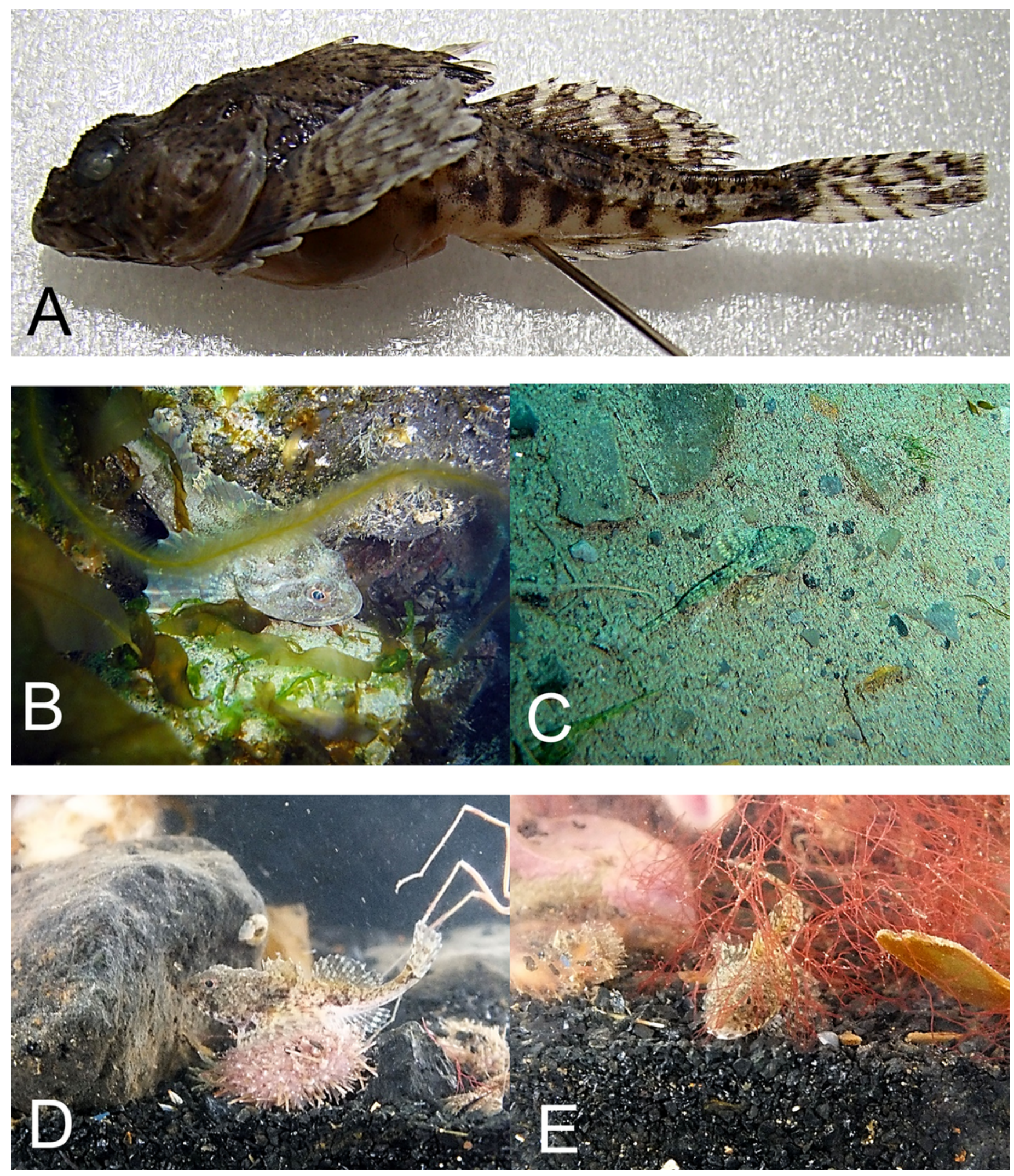
6

Bigeye sculpin (Triglops nybelini) observed in the mouth of a Black guillemot (Cepphus grylle), Torup Island, 20.08.2013.

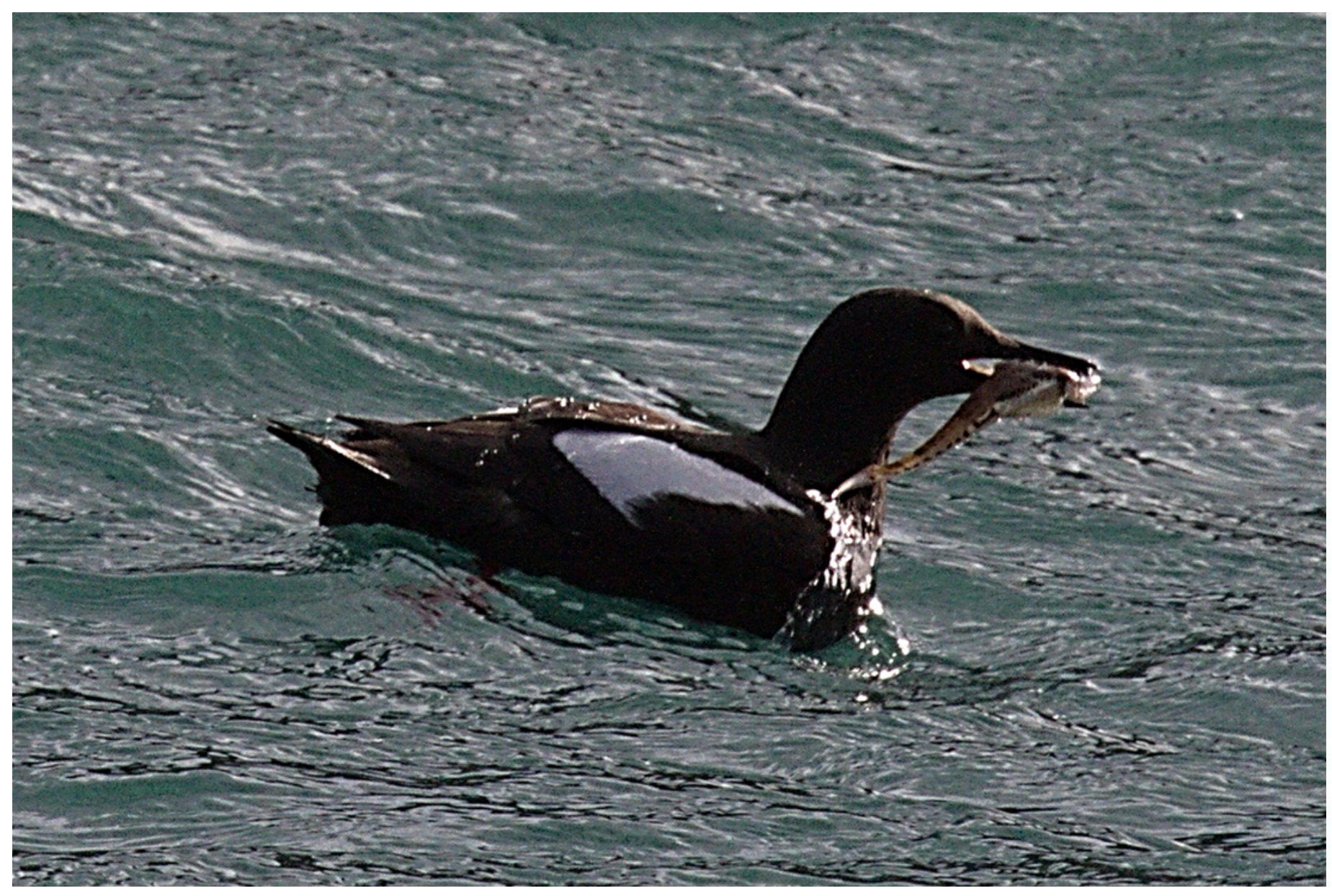




\section{7}

Atlantic spiny lumpsucker, Eumicrotremus spinosus.

A - Bliss Island, body is entirely covered by spiny plates; two pair of tubular nostrils are visible on snout in front of eye; barbels on chin present. B - Juvenile sitting on Laminaria sp.; caudal portion is nearly equal to trunk length. 
A

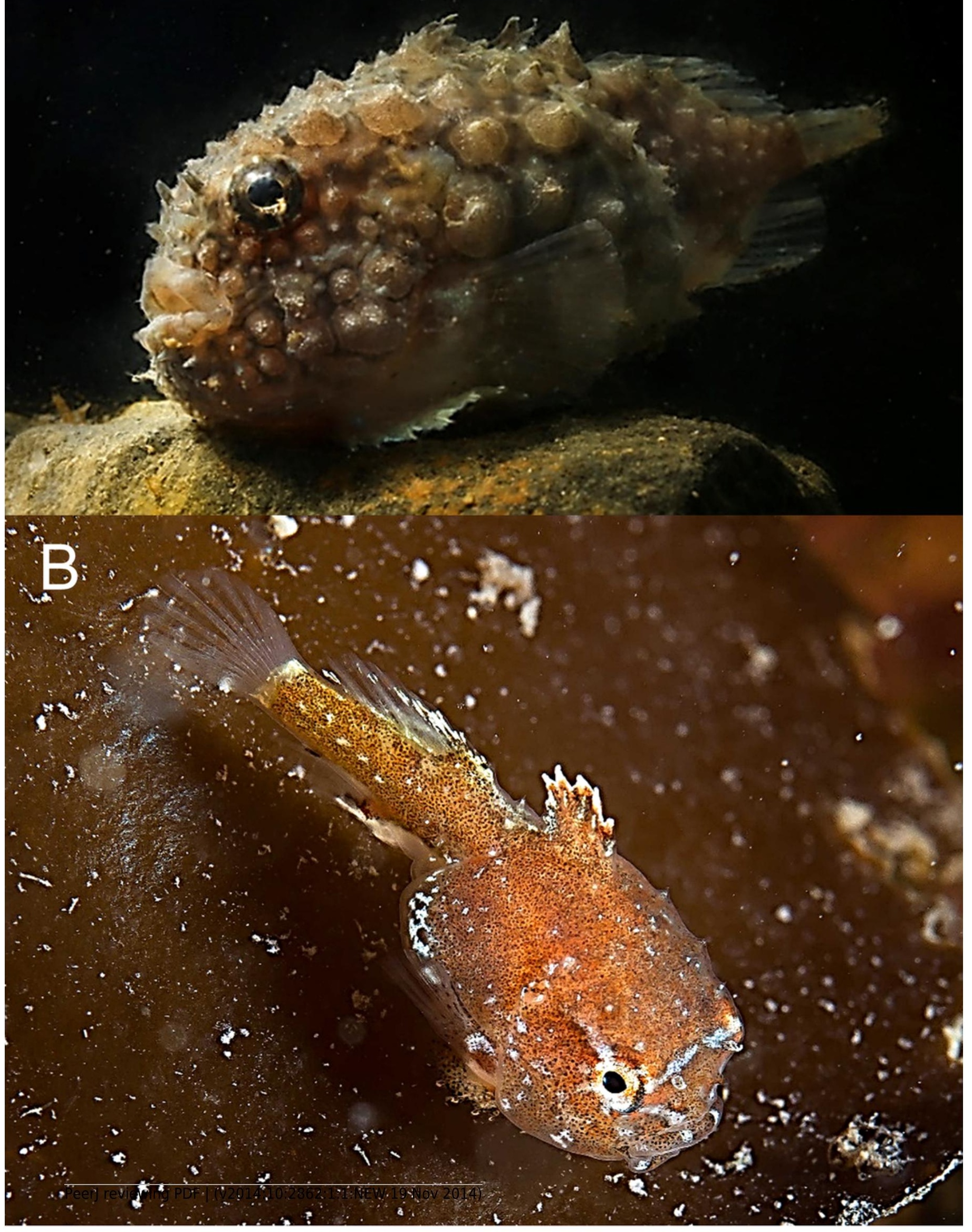




\section{8}

Derjugin's leatherfin lumpsucker, Eumicrotremus derjugini.

A - Young, Zub Island; forehead prominent, snout abruptly vertical; spiny plates weakly developed and small, appearing in three longitudinal short rows, 3 to 4 plates each; color is light brown with dark twisting lines. B - Same specimen from below; sucking disk consists of transformed ventral fins. C - Juvenile TL 14 mm, Prince Rudolf Island, ZIN 6-013/10; the first dorsal fin already covered by thickened skin. D - Same specimen after preservation.
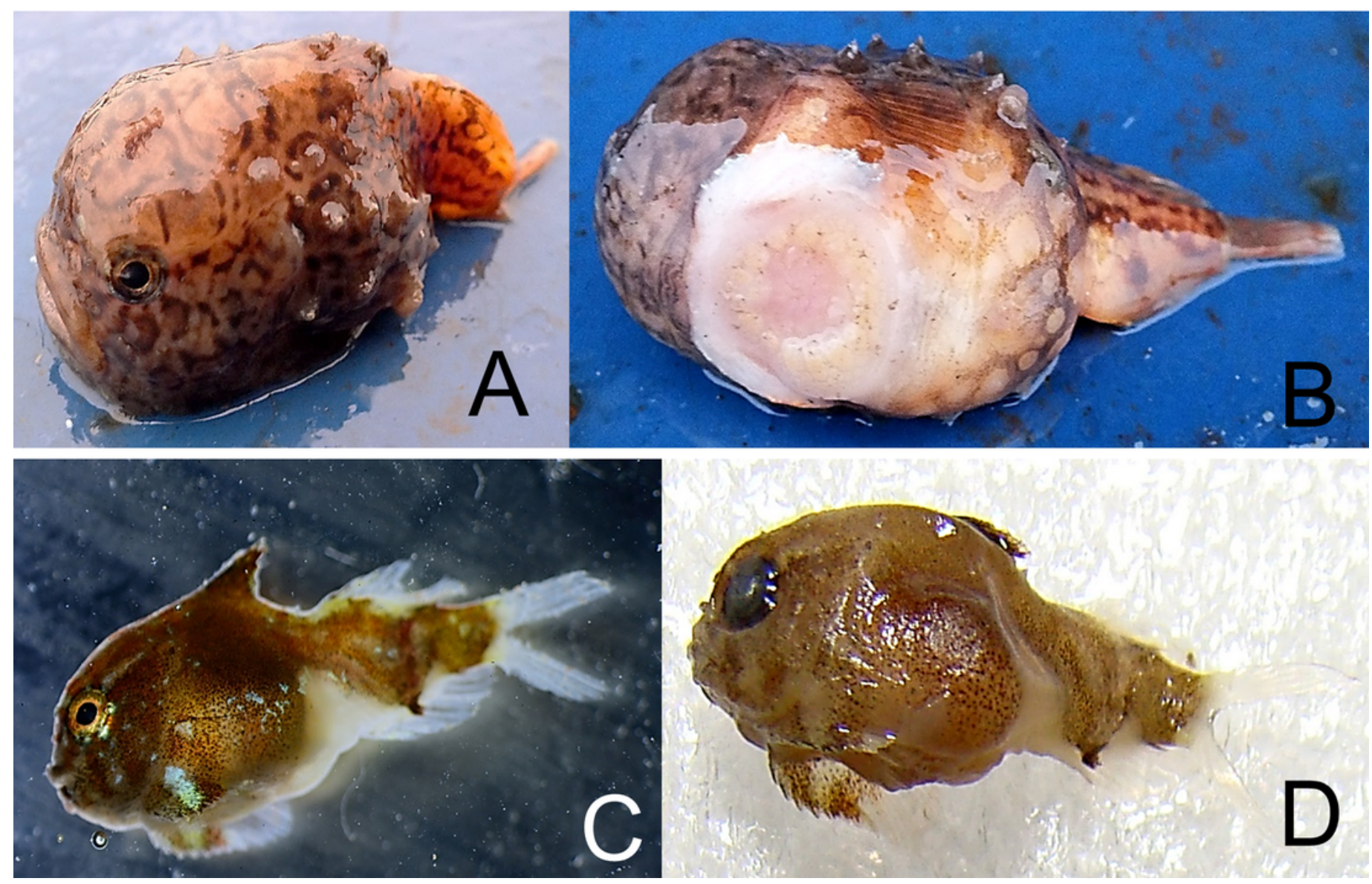
9

McAlpin's smooth lumpfish, Cyclopteropsis mcalpini, collected between Torup and Howen islands.

A - Adult $30 \mathrm{~mm}$ in length; sitting on Neptunea sp. shell; egg clutch is visible inside the shell.

B, C - Close-up of same specimen. D, E - Embryo, extracted from egg, which was attached to Neptunea sp. shell; yolk sack is large, sucking disk present.

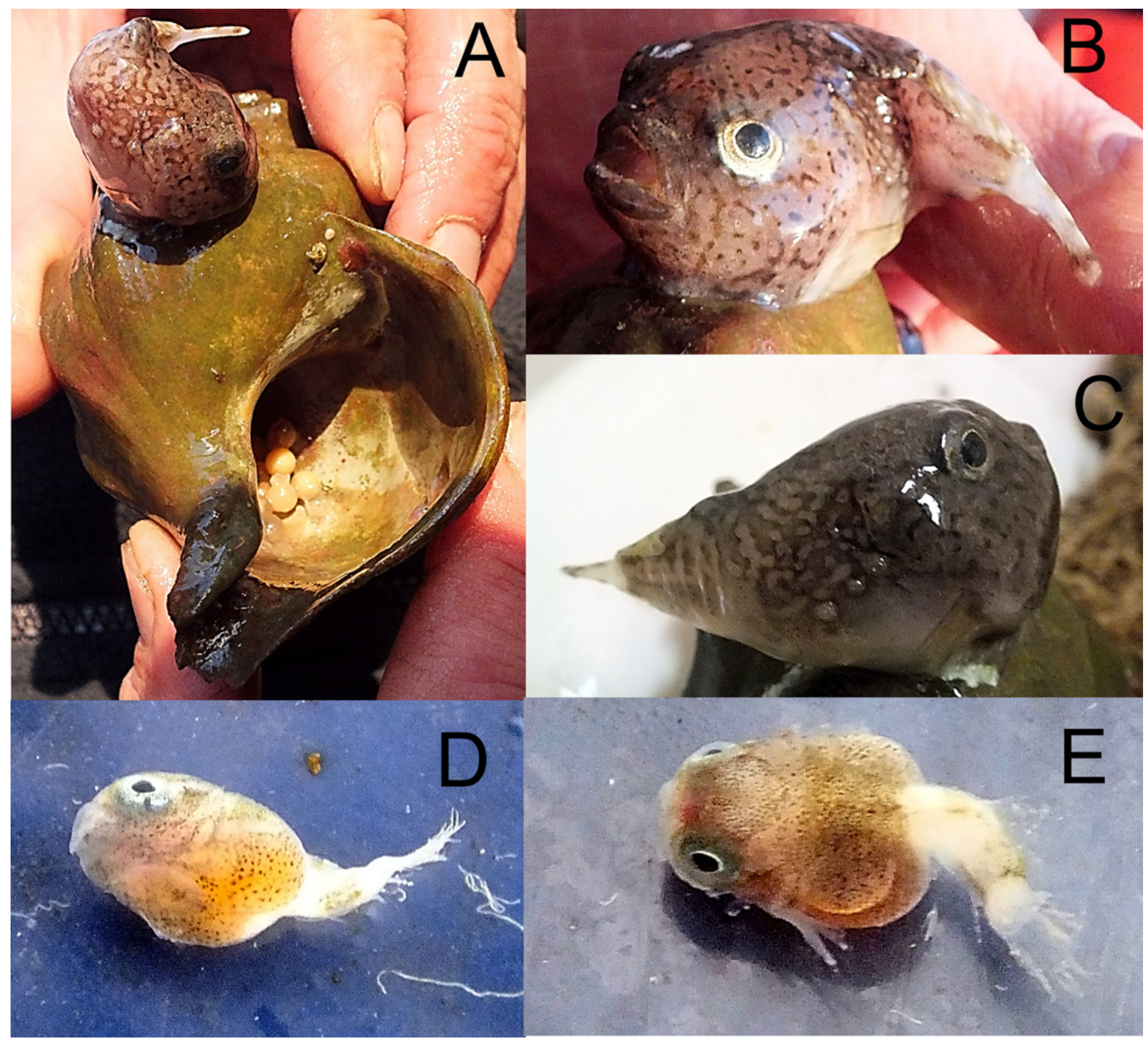




\section{0}

Parr's snailfish, Liparis bathyarcticus.

A-B - Young specimens alive, TL 41 mm, Hayes Island, ZIN 6-013/3; color orange-brownish. C - Same specimen; color brown after death; D - Juvenile TL15 mm captured in plankton net; Pioneer Island, ZIN 6-013/33. E - In situ specimen TL 41 mm.

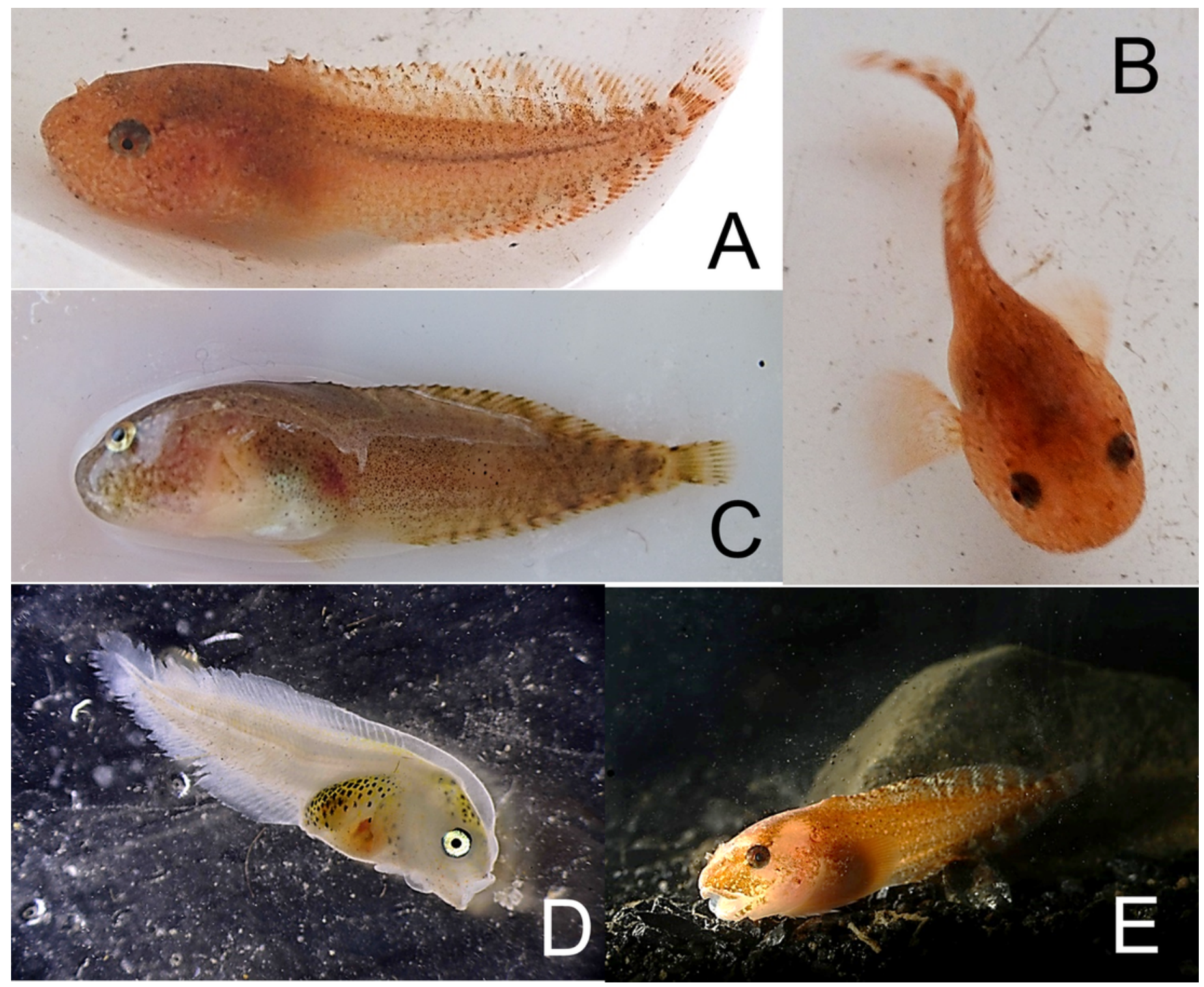




\section{1}

Kelp snailfish, Liparis tunicatus.

A - Female TL 137 mm, Prince Rudolf Island, ZIN 6-013/9. B - A pair in situ, Stolichki Island, ZIN 6-013/11.

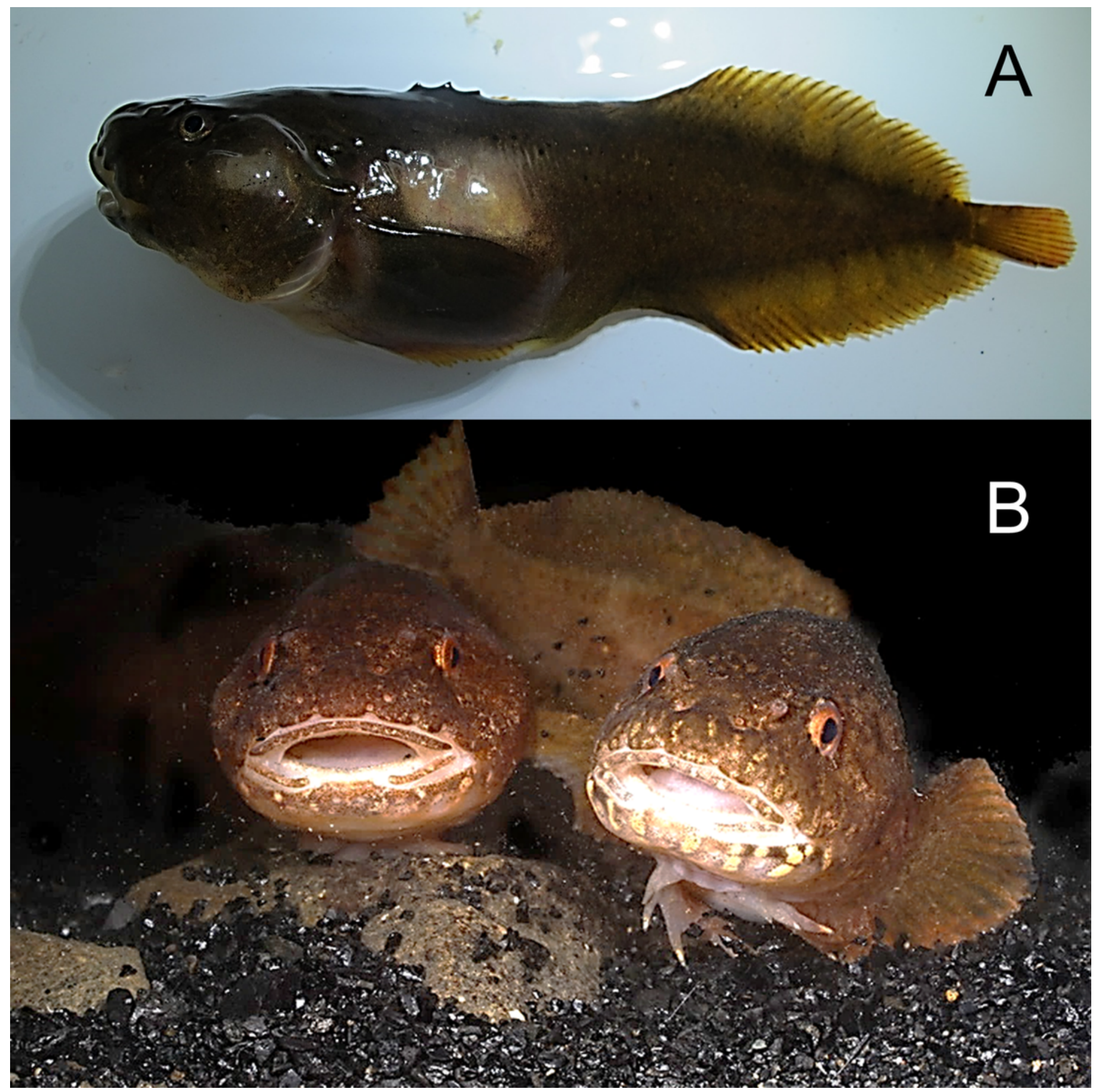


12

Blackbelly snailfish, Liparis cf. fabricii.

A - Adult male TL 165 mm from Luigi Island in aquarium, ZIN 6-013/13; note elongated pectoral fin lower-lobe rays with tactile receptors. B - Specimen from Mable Island in aquarium. C-D - Length TL 106 mm, view from above and below; Bell Island. E - Young specimen TL 72 mm; collected in plankton net; dark spots are distinct on transparent fins; black peritoneum hidden by silvery pigmentation. F - Young TL $33 \mathrm{~mm}$ after preservation, ZIN $6-013 / 32$. 

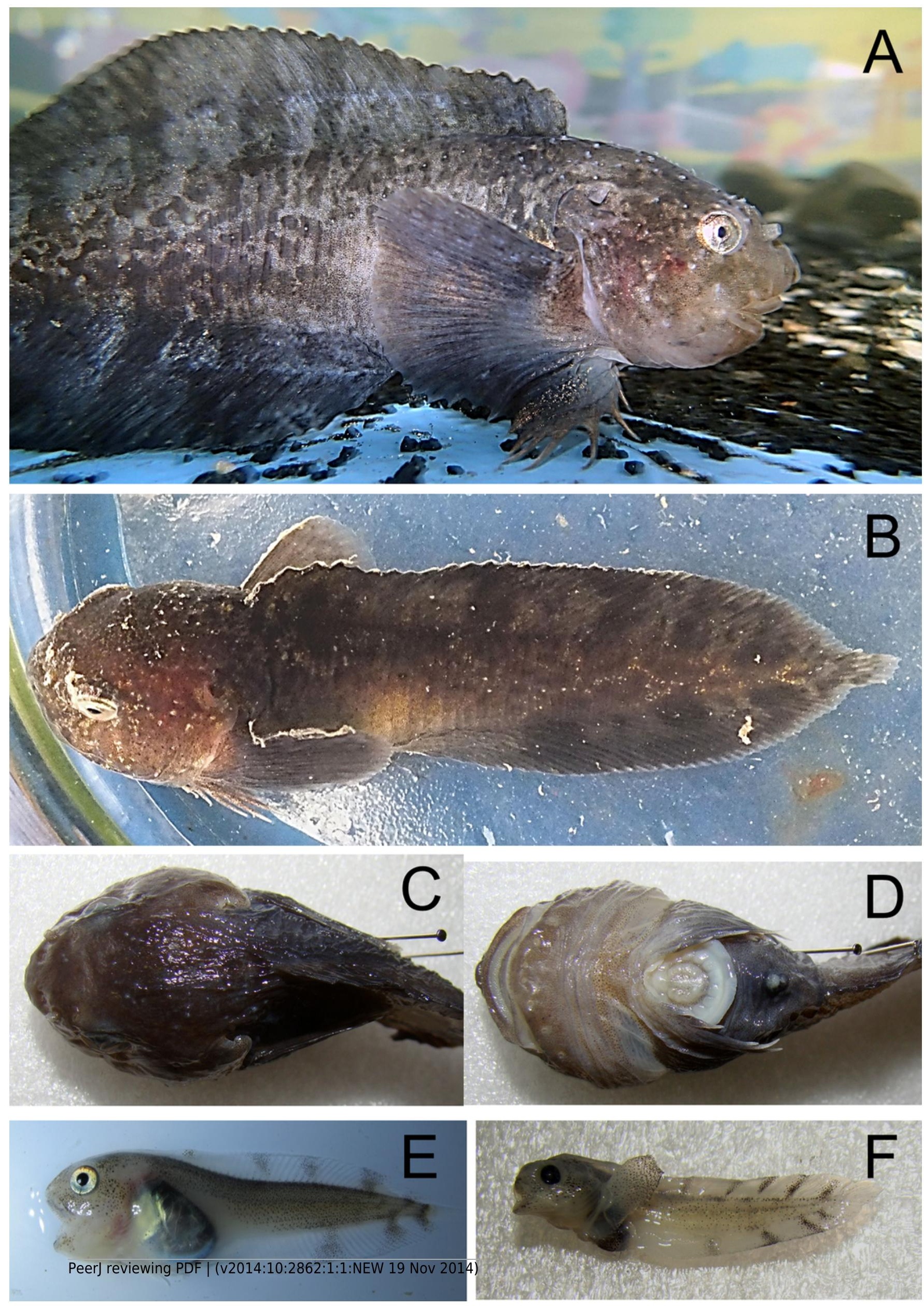


\section{3}

Arctic eelpout, Lycodes reticulates, Hayes Island.

A - Specimen in aquarium, color is dark, brown-black, bright light spots and transversal bands are present. B - Arctic eelpout in situ, hidden in a shelter under rocks. C - Same aquarium specimen as above.
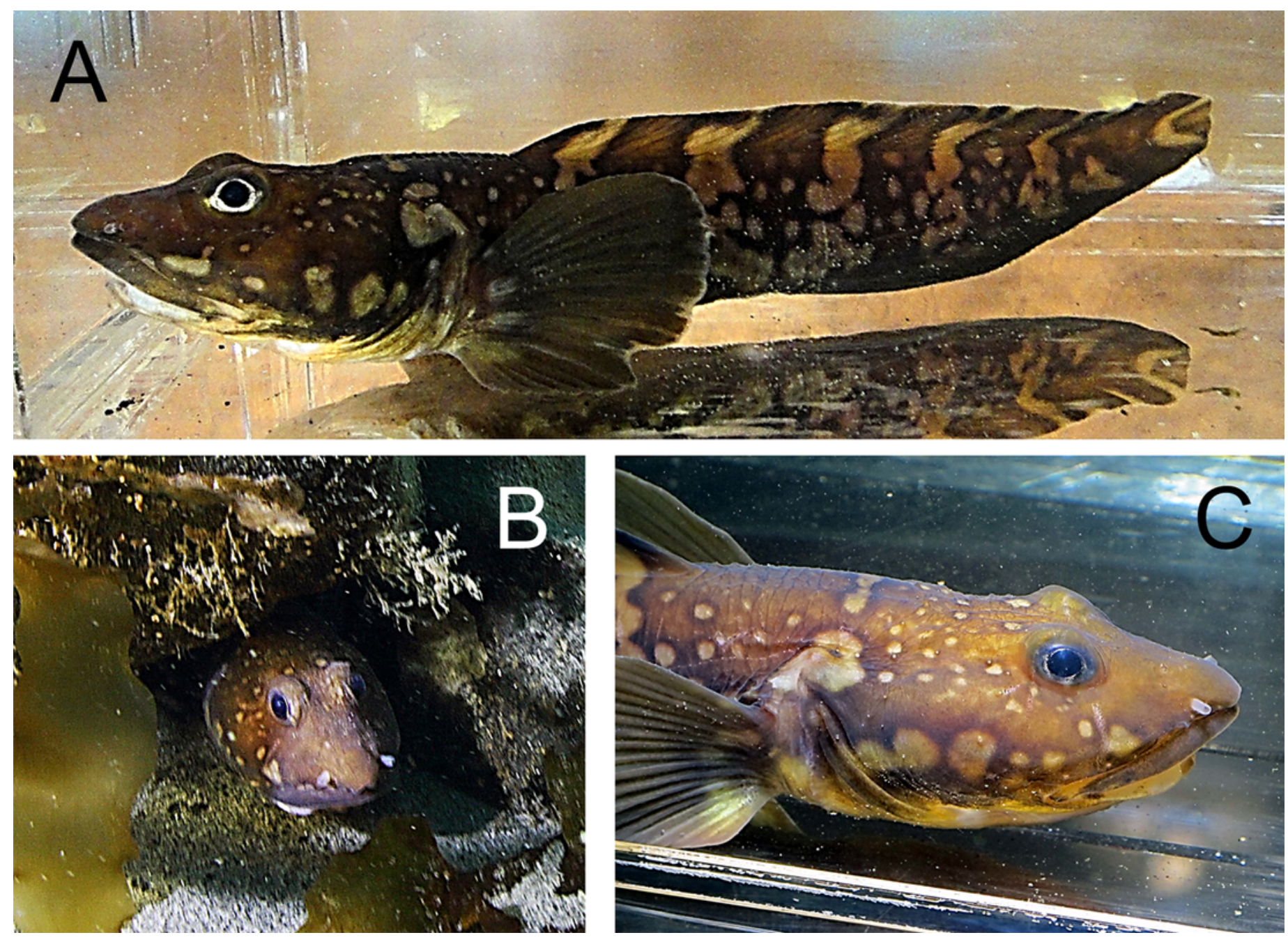


\section{4}

Anderson's pout, Gymnelus andersoni, male TL 120 mm, ZIN 6-013/1.

Specimen found on ship's deck, partially digested and likely deposited by a seabird. Dorsal fin origin near dissecting needle. Buccal muscle enlarged and prominent (sexual dimorphism). Indistinct vertical light brown and pale wide bands alternating on body.

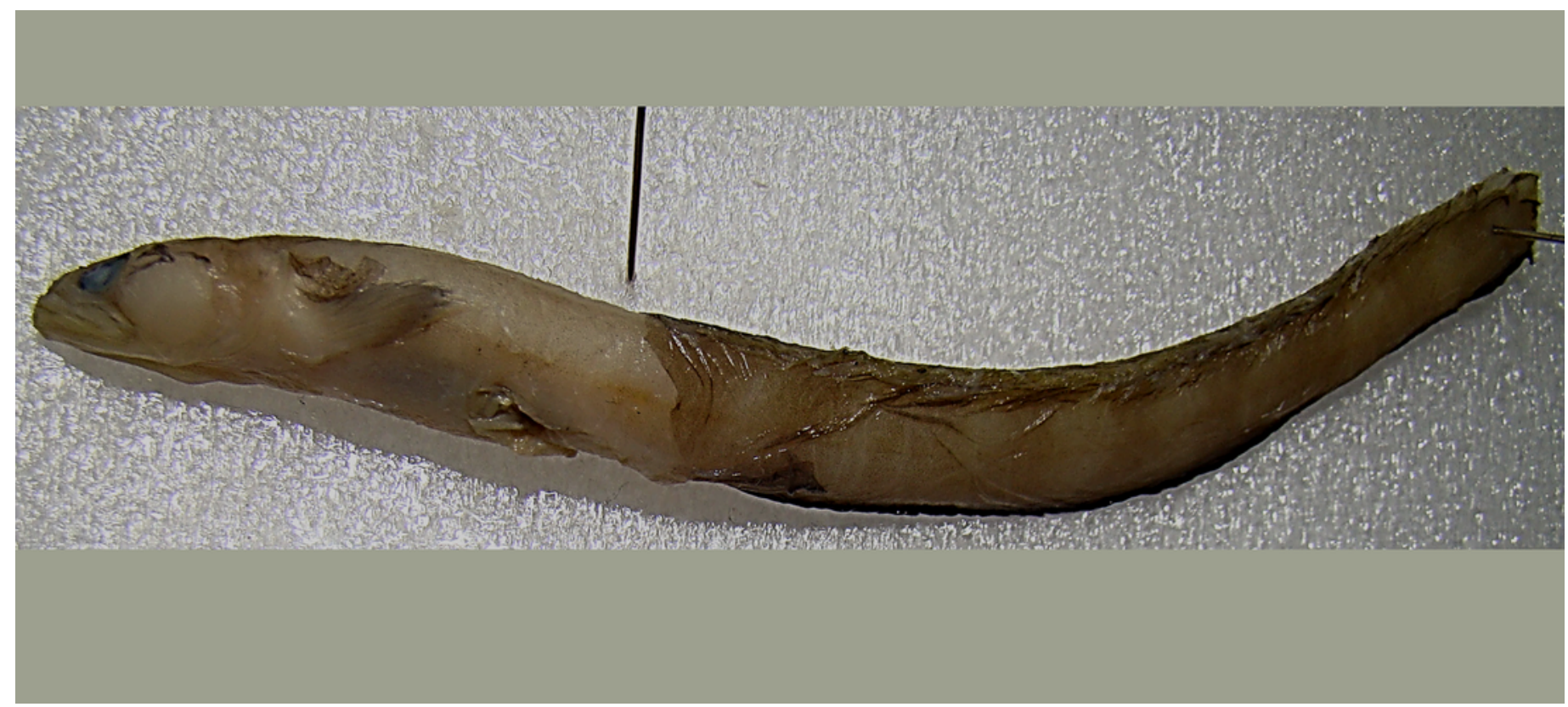


15

Esipov's pout, Gymnelus esipovi, male TL 141 mm, Wilton Island.

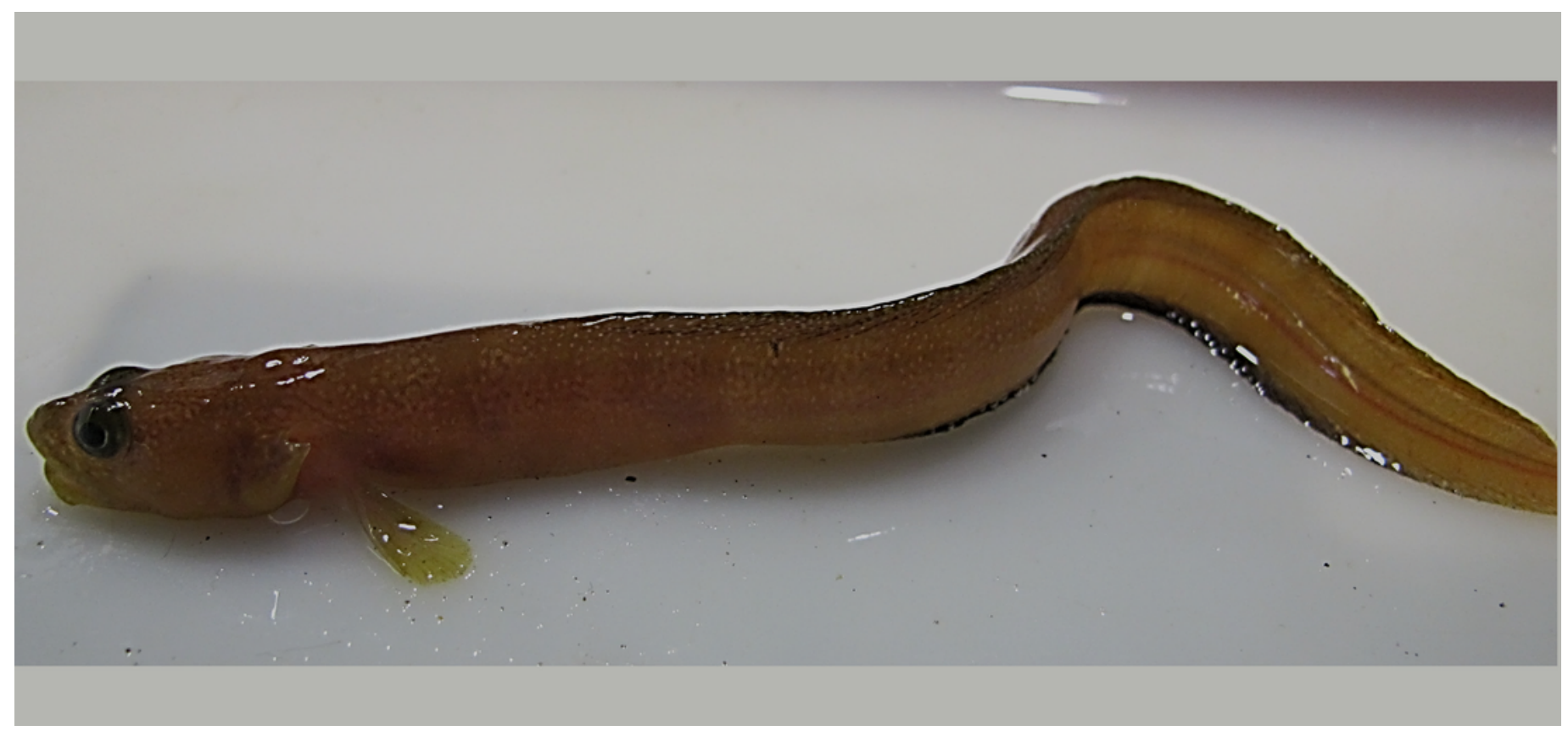

